Embracing open innovation to acquire external ideas and technologies and to transfer internal ideas and technologies outside

Mokter Hossain 


\section{Embracing open innovation to acquire external ideas and technologies and to transfer internal ideas and technologies outside}

\section{Mokter Hossain}

A doctoral dissertation completed for the degree of Doctor of Science (Technology) to be defended, with the permission of the Aalto University School of Science, at a public examination held at the lecture hall TU1 of the school on 18 August 2016 at 12 . 
Supervising professors

Professor llkka Kauranen

Aalto University, Finland

\section{Preliminary examiners}

Professor Saku Mäkinen

Tampere University of Technology, Finland

Professor Soumodip Sarkar

University of Évora, Portugal

\section{Opponents}

Professor Maria Elmquist

Chalmers University of Technology, Sweden

Aalto University publication series

DOCTORAL DISSERTATIONS 128/2016

(c) Mokter Hossain

ISBN 978-952-60-6893-0 (printed)

ISBN 978-952-60-6894-7 (pdf)

ISSN-L 1799-4934

ISSN 1799-4934 (printed)

ISSN 1799-4942 (pdf)

http://urn.fi/URN:ISBN:978-952-60-6894-7

Unigrafia Oy

Helsinki 2016

Finland 
Author

Mokter Hossain

Name of the doctoral dissertation

Embracing open innovation to acquire external ideas and technologies and to transfer internal ideas and technologies outside

\begin{tabular}{|c|c|}
\hline \multicolumn{2}{|l|}{ Publisher School of Science } \\
\hline Unit Department of Industrial Engineering and Manag & sement \\
\hline \multicolumn{2}{|c|}{ Series Aalto University publication series DOCTORAL DISSERTATIONS 128/2016 } \\
\hline \multicolumn{2}{|l|}{ Field of research Technology and knowledge management } \\
\hline Manuscript submitted 18 April 2016 & Date of the defence 18 August 2016 \\
\hline Permission to publish granted (date) 9 June 2016 & Language English \\
\hline$\bigotimes$ Article dissertation & $\square$ Essay dissertation \\
\hline
\end{tabular}

\section{Abstract}

The objective of this dissertation is to increase understanding of how organizations can embrace open innovation in order to acquire external ideas and technologies from outside the organization, and to transfer internal ideas and technologies to outside the organization. The objective encompasses six sub-objectives, each addressed in one or more substudies.

Altogether, the dissertation consists of nine substudies and a compendium summarizing the substudies.

An extensive literature review was conducted on open innovation and crowdsourcing literature (substudies 1-4). In the subsequent empirical substudies, both qualitative research methods (substudies 5-7) and quantitative research methods (substudies 8-9) were applied. The four literature review substudies provided insights on the body of knowledge on open innovation and crowdsourcing. These substudies unveiled most of the influential articles, authors, and journals of open innovation and crowdsourcing disciplines. Moreover, they identified research gaps in the current literature.

The empirical substudies offer several insightful findings. Substudy 5 shows how non-core ideas and technologies of a large firm can become valuable, especially for small firms.

Intermediary platforms can find solutions to many pressing problems of large organizations by engaging renowned scientists from all over world (substudy 6). Intermediary platforms can also bring breakthrough innovations with novel mechanisms (substudy 7 ). Large firms are not only able to garner ideas by engaging their customers through crowdsourcing but they can also build long-lasting relations with their customers (substudies 8 and 9). Embracing open innovation brings challenges for firms too.

Firms need to change their organizational structures in order to be able to fully benefit from open innovation. When crowdsourcing is successful, it produces a very large number of new ideas. This has the consequence that firms need to allocate a significant amount of resources in order to identify the most promising ideas. In an idea contest, customarily, only one or a few best ideas are rewarded (substudy 7). Sometimes, no reward is provided for the selected idea (substudies 8 and 9). Most of the ideas that are received are not implemented in practice.

Keywords Open innovation, crowdsourcing, ideas, technologies, knowledge

\begin{tabular}{lll}
\hline ISBN (printed) $978-952-60-6893-0$ & \multicolumn{3}{l}{ ISBN (pdf) $978-952-60-6894-7$} \\
\hline ISSN-L 1799-4934 & ISSN (printed) $1799-4934$ & ISSN (pdf) 1799-4942 \\
\hline Location of publisher Helsinki & Location of printing Helsinki & Year 2016 \\
\hline Pages 204 & urn http://urn.fi/URN:ISBN:978-952-60-6894-7 \\
\hline
\end{tabular}





\section{Acknowledgements}

This dissertation has only been possible with the advice, suggestions, support, and cooperation of a wide range of persons and organizations. Firstly, I am highly indebted to my supervisor Professor Ilkka Kauranen who has been an encouraging and intellectually challenging adviser, always full of ideas and having the time to discuss issues both inside and outside the academic world. Without his incessant encouragement, enthusiasm, and support, this work could not have been completed. My very deep gratitude for everything Professor Ilkka Kauranen has done for this dissertation!

I am greatly indebted to my family members who sacrificed a lot for me and always encouraged me to pursue my doctoral study. Many friends, neighbors, relatives, acquaintances and well-wishers have helped me in various capacities. I am really grateful to them.

I am grateful to the Department of Industrial Engineering and Management in particular and to Aalto University in general for facilitating the necessary support to pursue my studies. Colleagues and co-authors were my sources of support and intellectual learning. I am thankful to all the co-authors who have made my research journey valuable. I express my deep gratitude to all the individuals and organizations who helped in various capacities, such as collecting data, gathering information, and providing interviews. I would like to acknowledge the editors and referees of journals and conferences in which my articles have been published.

I highly appreciate my colleagues who took the time to give comments and challenge my thoughts, which consequently led me to refine my knowledge and understanding regarding research and beyond. My longtime colleague Mr. Ilpo Ervasti was a part of my everyday life, both in academic and social aspects. His numerous forms of support are highly appreciated. I am filled with gratitude for all the support I got from him. The debate and discussion I have had with my colleague Pardeep Maheshwari is truly memorable. I remember his contribution with great respect.

This dissertation would not have become a reality without the financial support from the following organizations: Aalto University, Academy of Finland, Finnish Cultural Foundation, and Marcus Wallenberg Foundation. I am very grateful to these organizations for supporting my doctoral studies. 
I express my deep acknowledgement to the pre-examiners Professor Saku Mäkinen from Tampere University of Technology, Finland, and Professor Soumodip Sarkar from University of Évora, Portugal for their insightful comments on the dissertation manuscript. Their comments and insightful suggestions helped me to sharpen the message of this dissertation. I feel privileged knowing that Professor Maria Elmquist from Chalmers University of Technology, Sweden has agreed to act as the opponent at oral defense of this dissertation. Finally, I would like to acknowledge the contribution of my adored parents whose blessings are always with me.

Helsinki, 18 June 2016

Mokter Hossain 


\section{Contents}

Acknowledgements .............................................................................

List of Publications ………................................................................... 5

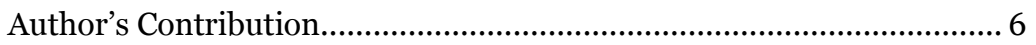

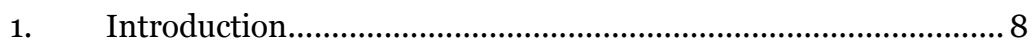

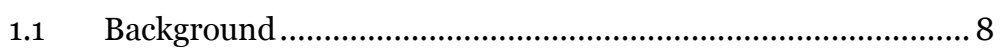

1.2 Objective of the dissertation ................................................ 9

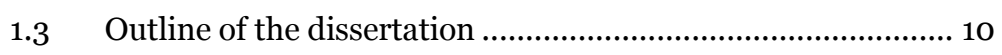

2. Open innovation and crowdsourcing …......................................13

$2.1 \quad$ Open innovation ..................................................................13

2.1.1 What is open innovation? ....................................................13

2.1.2 Open innovation as a phenomenon ....................................14

2.1.3 Critiques of open innovation...............................................15

2.1.4 Common implementations of open innovation ....................16

2.1.5 Outside-in process............................................................... 17

2.1.6 Inside-out process .................................................................17

2.1.7 Coupled process ................................................................18

2.2 Crowdsourcing .....................................................................19

2.2.1 What is crowdsourcing? .....................................................19

2.2.2 Crowdsourcing as a phenomenon ...................................... 20

2.2.3 Critiques of crowdsourcing ..................................................20

2.2.4 Common implementations of crowdsourcing......................21

2.2.5 Idea contests................................................................ 22

2.2.6 Online community......................................................... 23

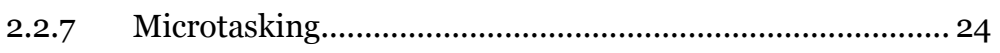

3. Method................................................................................ 25

3.1 Research approach........................................................... 25

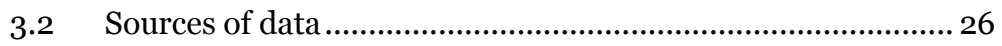

$3.3 \quad$ Data collection .................................................................. 26

$3.4 \quad$ Research techniques ......................................................... 26 


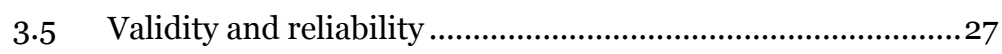

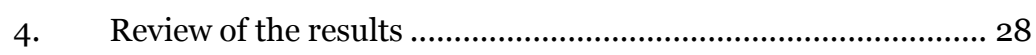

4.1 A review of open innovation literature................................. 28

4.2 An analysis of open innovation literature .............................29

4.3 A review of open innovation in SMEs ....................................29

4.4 A review of crowdsourcing literature .................................... 30

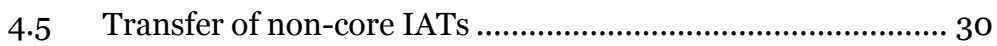

4.6 Motivations, challenges, and opportunities of solvers ............. 31

4.7 Competition-based breakthrough innovation.......................... 31

4.8 Ideation on the IdeaStorm platform .......................................32

4.9 Ideation on the My Starbucks Idea platform ….......................32

5. Implications ..........................................................................3

5.1 Theoretical implications ..........................................................33

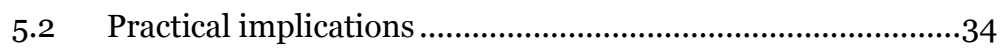

6. Limitations and future research directions................................36

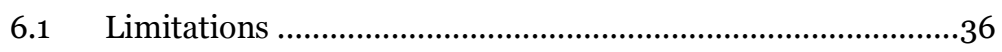

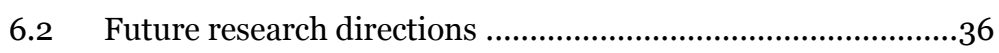

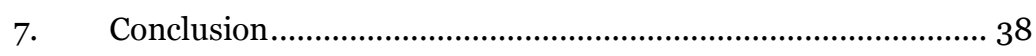

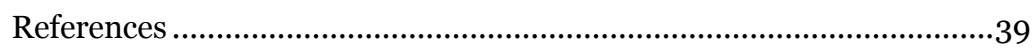

Appendix …................................................................................. 47 


\section{List of Publications}

This doctoral dissertation consists of a summary and the following nine substudies:

1. Hossain, M., Islam, K. M. Z., Sayeed, M. \& Kauranen, I. (2016). A comprehensive review of open innovation literature. Journal of Science and Technology Policy Management, 7 (1), 2-25.

2. Hossain, M., \& Anees-ur-Rehman, M. (2016). Open innovation: An analysis of twelve years of research. Strategic Outsourcing: An International Journal, 9(1), 22-37.

3. Hossain, M., \& Kauranen, I (2016). Open innovation in SMEs: A systematic literature review. Journal of Strategy and Management, 9 (1), 5873 .

4. Hossain, M., \& Kauranen, I. (2015). Crowdsourcing: A comprehensive literature review. Strategic Outsourcing: An International Journal, $8(1), 2-22$.

5. Hossain, M., \& Simula, H. Rising from the ashes - turning the non-core ideas and technologies of a large firm into new business, 16 pages (revised and resubmitted to Global Economics and Management Review).

6. Hossain, M. Motivations, challenges, and opportunities of successful solvers on an online innovation platform, 13 pages (revised and resubmitted to $R \& D$ Management).

7. Hossain, M., \& Kauranen, I. (2014). Competition-based innovation: The case of the X Prize Foundation. Journal of Organization Design, 3(3), $46-52$.

8. Hossain, M., \& Islam, K. M. Z. (2015a). Ideation through online open innovation platform: Dell IdeaStorm. Journal of the Knowledge Economy, 6(3), 611-624.

9. Hossain, M., \& Islam, K. M. Z. (2015b). Generating ideas on online platforms: A case study of "My Starbucks Idea". Arab Economic and Business Journal, 10(2), 102-111. 


\section{Author's Contribution}

Substudy 1: A comprehensive review of open innovation literature.

Contributions: Hossain developed the idea of the paper, collected the necessary articles based on systematic searching, and wrote the first draft, which was subsequently developed by all authors.

Substudy 2: Open innovation: An analysis of twelve years of research.

Contribution: Hossain developed the idea of the paper. He collected, sorted, and organized articles for review purposes. Both authors extracted the necessary information from selected articles, tabulated it on spreadsheets and created the results. Hossain wrote all the sections of the paper whereas the other author commented throughout the development of the process.

Substudy 3: Open innovation in SMEs: A systematic literature review.

Contributions: Hossain developed the idea of the paper, collected the necessary articles based on a systematic search, and wrote the first draft, which was subsequently developed by both authors.

Substudy 4: Crowdsourcing: A comprehensive literature review.

Contributions: Hossain developed the idea of the paper, collected the necessary articles based on a systematic search, and wrote the first draft, which was subsequently developed by both authors.

Substudy 5: Rising from the ashes - turning the non-core ideas and technologies of a large firm into new business.

Contributions: Hossain developed the idea of the paper and contributed to the theoretical section. Simula conducted the interviews for this study. Both authors refined the paper to its present state.

Substudy 6: Motivations, challenges, and opportunities of successful solvers on an online innovation platform.

Contributions: Hossain is the sole contributor to this study. 
Substudy 7: Competition-based innovation: The case of the X Prize Foundation.

Contributions: Hossain developed the idea of the paper and wrote the first draft. Hossain refined the paper based on comments of Kauranen. Subsequently the paper was developed by both authors.

Substudy 8: Ideation through online open innovation platform: Dell IdeaStorm.

Contributions: Hossain developed the idea of the paper, collected data, and wrote the first draft. Islam was involved with analysis of the data, primarily based on Hossain's suggestions. Both authors worked together to complete the paper.

Substudy 9: Generating ideas on online platforms: A case study of "My Starbucks Idea".

Contributions: Hossain developed the idea of the paper, collected data, and wrote the first draft. Islam was involved with analysis of the data, primarily based on Hossain's suggestions. Both authors work together to complete the paper. 


\section{Introduction}

\subsection{Background}

Ever since the open innovation concept was introduced by Chesbrough (2003), it has generated an avalanche of interest from academics and practitioners (West et al., 2014). Open innovation entails a new way of thinking about research and development (R\&D), shifting R\&D activities from internal discovery to external engagement (Tucci et al., 2016). Open innovation process is designed to manage inflows and outflows of knowledge across organizational boundaries (Chesbrough and Bogers, 2014). By means of engaging into open innovation, firms can find and integrate external knowledge for their internal innovation activities and take their unutilized internal knowledge to the external environment (Dahlander and Gann, 2010; Tucci et al., 2016). Significant organizational changes in terms of governance structure and individual routines are essential for firms when searching solutions from external engagement and when taking internal unutilized technologies outside (Chiaroni et al., 2010). Open innovation enables firms to gain a substantial increase in their R\&D efficiency. Hence, it has made a significant impact.

Various research streams of open innovation are emerging in the literature. These research streams include searching solutions of particular internal problems outside firms' boundaries (Jeppesen and Lakhani, 2010), and trading technologies (Dushnitsky et al., 2011). The breadth and depth of searching are crucial in open innovation (Laursen and Salter, 2006). Firms embrace open innovation to search beyond their boundaries when their performance do not match with their aspirations (Oliver et al., 2016).

Open innovation literature started with case-based studies in a limited number of industries within USA (Chesbrough, 2003). It has expanded its scope into many industries and regions over time (West et al., 2014). Various conceptualizations of open innovation have also evolved. Studies have investigated the prevalence, antecedents, and outcomes of openness (Alexy et al., 2016). Crowdsourcing literature emerged as an independent discipline three years after the conception of the open innovation literature (Howe, 2006). These two streams of literature are becoming closer to each other. Some scholars argue that crowdsourcing falls under the umbrella concept of open innovation (Ebner et al. 2009; Wikhamn and Wikhamn, 2013).

Even though understanding of open innovation and crowdsourcing has progressed significantly, a deep understanding of their numerous facets is still limited (Tucci et al., 2016). Hence, a better knowledge of how firms can use open 
innovation and crowdsourcing as a part of their business is called for (Tucci et al., 2016). There is a range of under-researched issues in the extant literature. This dissertation attempts to explore some of those issues with the nine partly overlapping substudies.

This dissertation explores various facets on open innovation and crowdsourcing using several theoretical perspectives. The literature review substudies point out theoretical advancements on the open innovation and crowdsourcing topics. Empirical substudies use theories from research domains of knowledge transfer, sourcing of ideas and technologies, innovation contest, motivation, innovation platform management, and technology management.

This dissertation reviews literature on open innovation in general comprehensively (substudies 1 and 2) and specifically in the context of small and mediumsized enterprises (SMEs) (substudy 3) in order to understand the development of open innovation literature and to identify research gaps. Similarly, a review of crowdsourcing literature is conducted in order to explore the overall development of this concept in the literature (substudy 4). Thus, the understanding of the literature on open innovation and crowdsourcing has been enhanced. Subsequently, substudies are pursued to explore open innovation and crowdsourcing in various empirical settings.

This dissertation empirically shows how a large firm adopted outbound open innovation in order to make its non-core ideas and technologies (IATs) available to startups which then commercialized the IATs supported with public funding. (substudy 5). As regards to inbound open innovation, two open innovation intermediary platforms were explored (IdeaConnection and X Prize). Using data from the IdeaConnection platform, motivations, challenges, and opportunities of successful solvers were identified (substudy 6). By exploring the X Prize platform, the dissertation provides insight into innovation contests, which are organized based on a novel approach in terms of financing and solutions. These contests have enabled to address the needs that are apparently impossible to pursue using any traditional approaches (substudy 7). Finally, the dissertation explores how crowds generate ideas on the online crowdsourcing platforms organized by large firms and how the best ideas are selected by the organizers (substudies 8 and 9). Thus, the dissertation contributes to several facets of the open innovation and crowdsourcing phenomena.

\subsection{Objective of the dissertation}

Open innovation is still a limitedly explored concept. Combining both internal and external knowledge, ideas, innovation, and technologies to serve their customers profitably is becoming increasingly important for firms. The objective of this dissertation is to increase understanding of how organizations can embrace open innovation in order to acquire external ideas and technologies from outside the organization, and to transfer internal ideas and technologies to outside the organization. The objective encompasses six sub-objectives. Each sub-objective is addressed in one or more substudies.

The sub-objectives of this dissertation are as follows: 
- To synthesize the extant literature on open innovation (covered in substudies 1, 2 and 3).

- To explore the development of crowdsourcing literature (covered in substudy 4).

- To demonstrate how a large firm adopted open innovation to deliver its IATs to startups (covered in substudy 5).

- To identify motivations, challenges, and opportunities of successful solvers to participate in virtual teams to solve problems on an intermediary online open innovation platform (covered in substudy 6).

- To provide insight about how competition-based innovation can be used in creating breakthrough innovation (covered in substudy 7).

- To identify factors associated with idea selection and implementation through online platforms (covered in substudies 8 and 9).

\subsection{Outline of the dissertation}

The dissertation encompasses two parts. The first part includes an overview of the dissertation, the objective of the dissertation, research methods, and reviews of the results of the substudies, along with implications and conclusions. The second part includes nine substudies that are either published or under review in peer-reviewed journals. These substudies contribute to the overall accomplishment of the objective. The substudies do not appear in chronological order in the dissertation. Rather, they follow the theoretical ground that is laid out in the first part. Table 1 presents the research techniques and data sources used in the nine substudies.

Table 1. The research techniques and data sources used in the substudies

\begin{tabular}{lll}
\hline Substudy & Research Technique & Data Type \\
\hline Substudy 1, 2, 3, and 4 & Systematic literature re- & Articles retrieved from the existing litera- \\
& view & ture \\
Substudy 5, 6, and 7 & Qualitative & Interviews and secondary publications \\
Substudy 8 and 9 & Quantitative & Data extracted from online crowdsourcing \\
& & platforms \\
\hline
\end{tabular}

The first substudy, A comprehensive review of open innovation literature, is a review study that explores open innovation literature in order to understand the overall development of this field. Along with a rich understanding of open innovation literature, this substudy identifies research gaps that need special attention from scholars. This substudy found that open innovation literature has given limited attention to open service innovation and inside-out open innovation, among others. Moreover, few scholars and a limited number of institutes represent studies on open innovation.

The second substudy, Open innovation: an analysis of twelve years of research, is also a review study. It explores patterns and developments in the open innovation literature over time. This substudy revealed issues that need special attention from scholars. The substudy found that Europe, as a region of data source, was higher in number than all other regions together. The firm level was dominant as the unit of analysis. Qualitative studies were mostly case based and 
quantitative studies were largely based on survey and panel data. Moreover, regression was a widely used analytical technique in open innovation studies.

The third substudy, Open innovation in small and medium-sized enterprises: A systematic literature review, is also a literature review. It concentrates particularly on open innovation in SMEs. This review study found that studies on open innovation have given limited attention in the context of SMEs. The review study revealed that SMEs are much less active than large firms in open innovation. However, the findings of some studies show that, in general, open innovation increases the overall innovation performance of SMEs. It is evident that SMEs adopt open innovation more for commercialization than for product development (van de Vrande et al., 2009; van Hemert et al., 2013).

The fourth substudy, Crowdsourcing: A comprehensive literature review, is a literature review study. It explores the overall development of crowdsourcing literature. The substudy found that crowdsourcing has been used for a wide range of applications. Furthermore, firms use crowdsourcing to accomplish simple to complex tasks. The substudy also identified avenues for future research. The above four literature review substudies provide a strong knowledge base with which to embark on empirical studies. Subsequently, five substudies were conducted as part of empirical studies and these studies are briefly discussed, as follows.

The fifth substudy, Rising from the ashes: Turning the non-core ideas and technologies of a large firm into new business, explores how, through the use of open innovation, a large firm (Nokia) delivered its non-core technologies to small firms with the support of state funding. This study implied that large firms can provide their non-core IATs to an external environment and thereby they can improve their brand image and business ecosystem.

The sixth substudy, Motivations, challenges, and opportunities of successful solvers on an online innovation platform, explores the major opportunities and challenges solvers face during their involvement in problem solving on an online platform. This substudy provides insightful knowledge for agencies who are involved in online open innovation platforms.

The seventh substudy, Competition-based innovation: The case of the X Prize Foundation, demonstrates how an open innovation platform, the X Prize Foundation, organizes prize competitions and brings out breakthrough innovations with novel approaches. The eighth substudy, Ideation through online open innovation platform: Dell IdeaStorm and the ninth substudy, User innovation on online platforms: A case study of "My Starbucks Idea", explore the crowdsourcing platforms of two large firms. Both the latter substudies (i.e. 8 \& 9) point out the major factors that are prevalent in the implementation of ideas, selected from a large number of ideas submitted by crowds.

The four review substudies and five empirical substudies together contribute valuable knowledge on the open innovation and crowdsourcing phenomena. This dissertation provides novel insights for academics and practitioners. The dissertation argues that the integration of the open innovation concept into business strategies is important in order for firms to flourish in their markets. The wide diffusion of the Internet, along with the advent of supporting tools and 
features, enables firms to embrace open innovation and crowdsourcing and tap knowledge from external sources. Policy makers should concentrate on developing policies that can nourish open innovation and crowdsourcing too. 


\section{Open innovation and crowdsourcing}

\subsection{Open innovation}

\subsubsection{What is open innovation?}

The open innovation concept has received considerable attention from both academics and practitioners (West et al., 2014). Sawhney Prandelli (2000) introduced the open innovation paradigm without making distinct articulation of the concept. Chesbrough (2003) is credited for the introduction of the open innovation concept. Chesbrough (2003, p. xxiv) defined the open innovation concept as follows: "open innovation is a paradigm that assumes that firms can and should use external ideas as well as internal ideas, and internal and external paths to market, as the firms look to advance their technology." Later, however, Chesbrough, along with his colleagues, proposed improved versions of the definition. Chesbrough and Bogers (2014) broaden the previous definition by emphasizing knowledge flows. They argue that flows of knowledge include knowledge inflows to the focal organization, outflows from the focal organization, and both of these types of flow (by coupling external knowledge sources and commercialization activities) (Chesbrough and Bogers, 2014). Table 2 presents some key definitions of open innovation.

Table 2. Definitions of open innovation

\begin{tabular}{|c|c|}
\hline Reference & Definition \\
\hline $\begin{array}{l}\text { Chesbrough (2003, p. } \\
\text { xxiv) }\end{array}$ & $\begin{array}{l}\text { "Open innovation is a paradigm that assumes that firms can and should use ex- } \\
\text { ternal ideas as well as internal ideas, and internal and external paths to market, } \\
\text { as the firms look to advance their technology." }\end{array}$ \\
\hline $\begin{array}{l}\text { Chesbrough et al. } \\
\text { (2006, p. vii) }\end{array}$ & $\begin{array}{l}\text { "Open innovation is the use of purposive inflows and outflows of knowledge to } \\
\text { accelerate internal innovation, and expand the markets for external use of inno- } \\
\text { vation, respectively. This paradigm assumes that firms can and should use ex- } \\
\text { ternal ideas as well as internal ideas, and internal and external paths to market, } \\
\text { as they look to advance their technology." }\end{array}$ \\
\hline $\begin{array}{l}\text { Lichtenthaler (2011, p. } \\
\text { 77) }\end{array}$ & $\begin{array}{l}\text { "Open innovation is defined as systematically performing knowledge explora- } \\
\text { tion, retention, and exploitation inside and outside an organization's boundaries } \\
\text { throughout the innovation process." }\end{array}$ \\
\hline Loren (2011, p. 5) & "Open innovation is the flow of ideas into and out of an organization." \\
\hline $\begin{array}{l}\text { Chesbrough and } \\
\text { Bogers }(2014, \text { p. 17) }\end{array}$ & $\begin{array}{l}\text { "Open innovation is a distributed innovation process based on purposively man- } \\
\text { aged knowledge flows across organizational boundaries, using pecuniary and } \\
\text { non-pecuniary mechanisms in line with each organization's business model." }\end{array}$ \\
\hline $\begin{array}{l}\text { Johannsson et al. } \\
(2015, \text { p. } 175)\end{array}$ & $\begin{array}{l}\text { "Open Innovation is the process of strategically managing the sharing of ideas } \\
\text { and resources among entities to co-create value." }\end{array}$ \\
\hline
\end{tabular}




\subsubsection{Open innovation as a phenomenon}

Although various definitions of open innovation allow us to get an understanding of the open innovation concept, distinguishing it from the closed innovation concept is essential in order to understand the open innovation concept to a fuller extent. Table 3 illustrates the main differences between open innovation principles and closed innovation principles. The charm and long-run success of closed innovation are increasingly waning due to the rapid change of information, technologies, innovation, collaboration, and competition, among other things (Almirall and Casadesus-Masanell, 2010). However, the way firms embrace open innovation varies due to their innovation requirements, organizational culture, and the timing of the implementation (Mortara and Minshall, 2011).

Table 3 shows some key differences between open innovation and closed innovation paradigms. The fundamental assumption of open innovation is that knowledge is distributed worldwide. Hence, firms cannot rely solely on their know-how, rather they need to explore knowledge from external sources, for example, through buying it or using in-licensing. In contrary, internal knowledge can be taken outside through out-licensing, joint ventures, or spinoffs. The open innovation concept assumes that not all smart people work for one particular firm. Firms need to work with people inside and outside of the firm. The internal R\&D of a firm needs to explore external R\&D to create significant value (Chesbrough, 2003). An idea does not necessarily need to originate from internal R\&D. Firms should benefit from their and others' intellectual properties (IPs). The closed innovation concept is the opposite of the open innovation concept. The closed innovation concept holds that firms have smart people, R\&D should be developed and shipped internally, and taken to market and thus firms gain revenue.

Table 3. Open innovation principles versus closed innovation principles (adopted from Chesbrough, 2003, p. xxvi)

\begin{tabular}{|c|c|}
\hline Open Innovation Principles & Closed Innovation Principles \\
\hline $\begin{array}{l}\text { "Not all the smart people work for us, so we must } \\
\text { find and tap into the knowledge and expertise of } \\
\text { bright individuals outside our company" }\end{array}$ & "Most of the smart people in our field work for us" \\
\hline $\begin{array}{l}\text { "External R\&D can create significant value; internal } \\
\text { R\&D is needed to claim some portion of that value" }\end{array}$ & $\begin{array}{l}\text { "To profit from R\&D, we must discover, develop } \\
\text { and ship ourselves" }\end{array}$ \\
\hline $\begin{array}{l}\text { "We don't have to originate the research in order to } \\
\text { profit from it" }\end{array}$ & "If we discover it, we will get it to market first" \\
\hline $\begin{array}{l}\text { "Building a better business model is better than get- } \\
\text { ting to market first" }\end{array}$ & "If we are the 1st to commercialize we will win" \\
\hline $\begin{array}{l}\text { "If we make the best use of internal and external } \\
\text { ideas, we will win" }\end{array}$ & $\begin{array}{l}\text { "If we create the most and the best ideas in the in- } \\
\text { dustry, we will win" }\end{array}$ \\
\hline $\begin{array}{l}\text { "We should profit from others' use of our IP, and we } \\
\text { should buy others' IP whenever it advances our own } \\
\text { business model" }\end{array}$ & $\begin{array}{l}\text { "We should control our intellectual property (IP) so } \\
\text { that our competitors don't profit from our ideas" }\end{array}$ \\
\hline
\end{tabular}

The open innovation concept holds that corporate innovation activities are similar to an open system (West and Lakhani, 2008). A number of special issues from journals such as Industry \& Innovation, International Journal of Technology Management, R\&D Management, Technovation, Research Policy, and 
Strategic Entrepreneurship Journal have driven open innovation to a new frontier (West et al., 2014). Open innovation has emerged in the development of systems of innovation (Sharif, 2006). It provides rich potential for fundamental discoveries regarding openness. Open innovation literature includes a range of literature reviews (e.g., Elmquist et al., 2009; West et al., 2006, Enkel et al., 2009, Dahlander and Gann, 2010; Giannopoulou et al., 2010; Lichtenthaler, 2011; Su and Lee, 2012; Schroll and Mild, 2012; Chesbrough and Bogers, 2014; West et al., 2014; West and Bogers, 2014). These review studies synthesized the state-of-the-art open innovation literature from various lenses.

West and Gallagher (2006) related open innovation to open-source software. They found three key challenges for firms wanting to embrace open innovation: (1) finding the creative means to exploit internal innovation, (2) incorporating external innovation, and (3) motivating outsiders to provide innovations from external sources. Firms can reveal some of their internal knowledge to external parties to gain benefits from external sources. Thus, the selective disclosure of internal knowledge to external sources brings significant benefits for firms (Henkel, 2006; Gruber and Henkel, 2006; Henkel et al., 2014). Open innovation is primarily explored in the large firms of high-tech industries (West et al., 2014). However, a seminal study by van de Vrande et al. (2009) has drawn special attention from scholars in regard to open innovation in SMEs. Subsequently, several scholars have focused on open innovation in SMEs (Bianchi et al., 2010; van Hemert et al. 2013; Lee et al., 2010; Parida et al., 2012). Studies on open innovation in SMEs found that embracing open innovation boosts the performance of SMEs as a whole. However, these studies revealed that SMEs consider open innovation more in the commercial stage than in the R\&D stage. More recent literature has broadened open innovation into the service sector (Chesbrough, 2010; Chesbrough, 2011; Mina et al., 2014; Gianiodis et al., 2014). These studies pointed out various facets of open innovation in the service sector. Chesbrough (2011) pointed out that most of IBM's revenues come from the service sector, even though IBM is known for its products (such as computer systems, servers, mainframes, and software). The studies found that many firms are more active in open service innovation than product innovation (Mina et al. 2014). For example, Gianiodis et al. (2014) showed how a financial institute accelerated organizational transformation by implementing an open service innovation model.

\subsubsection{Critiques of open innovation}

As the open innovation concept has received (and is still receiving) increasing attention from a wide variety of disciplines and scholars, so have critiques of the concept. Several scholars have strongly criticized the veracity of the open innovation concept (Mowery, 2009; Trott and Hartmann, 2009; Groenand and Linton, 2010). For example, Trott and Hartmann (2009) argued that no firms have ever followed closed innovation and that firms have always practiced open innovation in their innovation processes. Thus, they point out that there is no real paradigm shift from the closed to open approach.

In line with the view of Trott and Hartmann (2009), Mowery (2009) argued that many elements of the open innovation approach were used in earlier periods, 
dating back to the late 19th century and early 2oth century. On the other hand, even though Groen and Linton (2010) acknowledge that a significant change has taken place in the past generation, they question the necessity of the open innovation concept. Moreover, they argue that the supply chain covers everything open innovation covers, as such the open innovation concept may deter communication among academics of various disciplines. Only recently, Chesbrough and Bogers (2014) responded to the critiques and reinforced the open innovation concept. Despite some criticisms, open innovation as a phenomenon is increasingly interesting to researchers and managers. The following section points out the common forms of the implementation of open innovation.

\subsubsection{Common implementations of open innovation}

Examples of the most common implementation of open innovation are insideout process, outside-in process, coupled process, co-creation, and crowdsourcing (Enkel et al., 2009; Huizingh, 2011; Johannsson et al., 2015). Open innovation significantly focuses on lead users, consumers, communities, partners (Lakhani et al., 2008; Hienerth, 2006; Lettl et al., 2006; Huizingh, 2011), universities, and research organizations (Perkmann and Walsh, 2007). The open innovation concept overlaps with concepts such as open-source model, user innovation, and open distributed innovation (von Hippel, 2005; West and Gallagher, 2006; West and Lakhani, 2008; Bogers et al., 2010; Hossain, 2013).

The inside-out and outside-in processes are also respectively named the outbound open innovation process and inbound open innovation process (Chesbrough and Crowther, 2006; Lichtenthaler, 2009; Huizingh, 2011). Moreover, Dahlander and Gann (2010) found two inbound processes (sourcing and acquiring) and two outbound process (revealing and selling). A recent review study by West and Bogers (2014) found that the majority of the studies address elements of the inbound open innovation process. However, internal R\&D activities and external knowledge sourcing have a positive effect on firms' innovation performance (Chen et al., 2015).

Open innovation has predominantly been explored in the manufacturing sector, whereas open innovation in the service sector only received attention at a later stage, especially after a book published by Chesbrough (2010) on open service innovation. Several studies have explored various facets of open service innovation (see Chesbrough, 2011; Mina et al., 2014; Gianiodis et al., 2014). Recently the "open social innovation" concept has been introduced as an extension of the broad open innovation phenomenon (Chesbrough and Di Minin, 2014). Open innovation studies mostly explore the organizational level, whereas other levels (such as individual, industry, and national levels) are limitedly explored in the literature (West et al., 2006).

No matter how promising external ideas are, a key challenge in open innovation is the not-invented-here (NIH) syndrome (Lichtenthaler and Ernst, 2006; Johannsson et al., 2015) - a belief that only internal ideas are valuable (Katz and Allen, 1982). Managers resist embracing open innovation due to the NIH syndrome (Lichtenthaler and Ernst, 2006). The main forms of the implementation of open innovation (outside-in process, inside-out process, and coupled process) are described in the following sections. 


\subsubsection{Outside-in process}

The outside-in process denotes the integration of suppliers, customers, competitors, and external knowledge to enrich a firm's internal knowledge base (Enkel et al., 2009). The largest body of research is on the outside-in mode of open innovation (Chesbrough and Crowther, 2006; Enkel et al., 2009; West and Bogers, 2014). Studies found that the outside-in mode of open innovation increases firms' internal innovativeness (Laursen and Salter, 2006; Lettl et al., 2006; West and Bogers, 2014) and has a significant positive impact on innovation performance (Inauen and Schenker-Wicki, 2011). In the outside-in process, firms can use a range of external sources, such as non-customers, and non-suppliers. They can integrate external experts through crowdsourcing and intermediaries such as IdeaConnection, InnoCentive, NineSigma, and Yet2.com (Hossain, 2012b).

Searching external knowledge is crucial for firms' innovative activities. Whether firms should search locally or distantly, on one hand, and experientially or cognitively, on the other, is a key issue in understanding questions such as where and how to search (Lopez-Vega et al., 2016). Firms bring in innovations from outside through crowdsourcing (Poetz and Schreier, 2012), co-creation (Prahalad and Ramaswamy, 2004), and technology transfer (Lichtenthaler and Lichtenthaler, 2010).

West and Bogers (2014) found that searching, enabling, filtering, and acquiring are the four major steps for the outside-in process. In the outside-in process, studies found that a firms' main external sources are customers (Grimpe and Sofka, 2009), suppliers (Schiele, 2010), competitors (Lim et al., 2010), and research institutes (Fabrizio, 2009). However, firms need to have internal R\&D capabilities and complementary assets for a successful outside-in process (Teirlinck et al., 2010). Organizational culture is crucial for firms to successfully benefit from external sources of innovation as the NIH attitude is a key barrier to their success (Laursen and Salter, 2006; West and Gallagher, 2006; Laursen and Salter, 2014). The origin of open innovation emphasizes the linear model (Chesbrough, 2003). However, other models-such as feedback loops, reciprocal interactions, and integration with external innovation communities-are also used (West and Bogers, 2014).

\subsubsection{Inside-out process}

The inside-out process refers to gaining benefits by taking one's ideas to market, selling IPs, and multiplying technology by transferring to the external environment (Enkel et al., 2009). The inside-out dimension has been relatively neglected in literature as most studies have explored the outside-in dimension (Lichtenthaler, 2009). With the inside-out process, firms can take ideas to market in shorter lead time than the other alternative (internal development). Firms should focus not only on their existing market but also engage in other areas, adopting licensing, spin offs, and joint ventures. Thus, firms create more overall revenue from the innovation (Lichtenthaler and Ernst, 2007). However, mostly large firms are actively involved with inside-out strategy, allocating it substantial resources. 
As a whole, firms are gaining increasing awareness of corporate venturing, business models, new ventures, spin-offs, and cross-industry innovation (Vanhaverbecke et al., 2008; Enkel and Gassmann, 2010). They can engage intermediaries and state organizations, and collaborate with other large firms in joint efforts (Hossain, 2012a). The inside-out process includes firms' innovation processes for exploitation. It is related to the commercialization of internal knowledge outside through, for example, out-licensing (Alexy et al., 2009). The inside-out mode is mainly limited to the commercialization phase and for technologies and knowledge spin-outs with the help of external organizations (Rohrbeck et al., 2009). Empirical studies on the inside-out process are very limited. An early quantitative empirical study by Lichtenthaler (2009) found a positive relationship between inside-out open innovation and a firm's performance.

\subsubsection{Coupled process}

The coupled process indicates co-creation with complementary partners via alliances, cooperation, and joint ventures where mutual sharing of knowledge is pivotal for success (Enkel et al., 2009). Firms can establish the coupled process by combining both the inside-out process and the outside-in process to develop and commercialize innovation together with a partner (Enkel et al., 2009; Huizingh, 2011). A common form of coupled process is co-creation (Enkel et al., 2009). Co-creation is studied under several disciplines including in open-source software and marketing (Prahalad and Ramaswamy, 2004; von Hippel and von Krogh, 2006; Füller, 2010). Moreover, Rohrbeck et al. (2009) found that coupled processes take place when established firms interact with each other. They identified that firms use foresight workshops and executive forums for information gathering and join development and strategic alliances for product development with partners. A large number of studies under coupled process involve dyadic collaboration between the innovation creator and the innovationseeking firm (West and Bogers, 2014). Open innovation literature possesses very few studies on the coupled process of open innovation. 


\subsection{Crowdsourcing}

\subsubsection{What is crowdsourcing?}

Howe (2006) is acknowledged for presenting the first definition of crowdsourcing. According to this definition, crowdsourcing "represents the act of a firm or institution taking a function once performed by employees and outsourcing it to an undefined (and generally large) network of people in the form of an open call." Over time, Howe has also proposed several other definitions of crowdsourcing. Numerous definitions of crowdsourcing are available in the extant literature (see Ribiere and Tuggle, 2010; Sloane, 2011). For example, Estellés-Arolas and González-Ladrón-de-Guevara (2012) found that there are at least 40 original definitions of crowdsourcing in the current literature. Some definitions of crowdsourcing are presented in table 4.

Table 4. Definitions of crowdsourcing

\begin{tabular}{|c|c|}
\hline Reference & Definition \\
\hline Brabham (2008, p. 79) & $\begin{array}{l}\text { "a strategic model to attract an interested, motivated crowd of individuals ca- } \\
\text { pable of providing solutions superior in quality and quantity to those that even } \\
\text { traditional forms of business can." }\end{array}$ \\
\hline $\begin{array}{l}\text { Kleemann and Voß } \\
(2008, \text { p. 22) }\end{array}$ & $\begin{array}{l}\text { "[a] form of the integration of users or consumers in internal processes of value } \\
\text { creation." }\end{array}$ \\
\hline $\begin{array}{l}\text { Porta et al. (2008, p. } \\
\text { 14) }\end{array}$ & $\begin{array}{l}\text { "enlisting customers to directly help an enterprise in every aspect of the lifecy- } \\
\text { cle of a product or service." }\end{array}$ \\
\hline Grier (2011, p. 1) & "a way of using the internet to employ large numbers of dispersed workers." \\
\hline Sloane (2011, p. 17) & $\begin{array}{l}\text { "one particular manifestation of open innovation. It is the act of outsourcing a } \\
\text { task to a large group of people outside your organization, often by making a } \\
\text { public call for response." }\end{array}$ \\
\hline $\begin{array}{l}\text { Poetz and Schreier } \\
(2012, \text { p. 246) }\end{array}$ & $\begin{array}{l}\text { "[to] outsource the phase of idea generation to a potentially large and unknown } \\
\text { population in the form of an open call." }\end{array}$ \\
\hline $\begin{array}{l}\text { Estellés-Arolas and } \\
\text { González-Ladrón-de- } \\
\text { Guevara (2012, p. 197) }\end{array}$ & $\begin{array}{l}\text { "[an] online activity in which an individual, an institution, a non-profit organ- } \\
\text { ization, or company proposes to a group of individuals of varying knowledge, } \\
\text { heterogeneity, and number, via a flexible open call, the voluntary undertaking } \\
\text { of a task. The undertaking of the task, of variable complexity and modularity, } \\
\text { and in which the crowd should participate bringing their work, money, } \\
\text { knowledge and/or experience, always entails mutual benefit. The user will re- } \\
\text { ceive the satisfaction of a given type of need, be it economic, social recognition, } \\
\text { self-esteem, or the development of individual skills, while the crowdsourcer } \\
\text { will obtain and utilize to their advantage what the user has brought to the ven- } \\
\text { ture, whose form will depend on the type of activity undertaken." }\end{array}$ \\
\hline
\end{tabular}

Open innovation and crowdsourcing are closely related terms. Although crowdsourcing literature originally emerged as an independent discipline, some scholars consider that crowdsourcing is merely one type of open innovation (Enkel et al., 2009; Johannsson et al., 2015). Sometimes crowdsourcing and open innovation have even been used interchangeably (Ebner et al., 2009; Marjanovic et al., 2012; Wikhamn and Wikhamn, 2013). In this dissertation, open innovation and crowdsourcing are acknowledged to be partly over-lapping concepts but they are, nevertheless, considered separate disciplines. Consequently, literature review study was conducted separately for both of these disciplines. 


\subsubsection{Crowdsourcing as a phenomenon}

Crowds are increasingly becoming a part of innovation. Large firms such as Apple, Cisco, and Unilever involve crowds to accelerate their business growth. Crowdsourcing is different from traditional organizational models for problem solving. According to Boudreau and Lakhani (2013), firms have a well-organized environment in which to address problems and innovation opportunities, whereas crowdsourcing is a loose and decentralized mechanism. In crowdsourcing, diverse individuals with varied skills are involved in problem solving. Crowdsourcing has emerged as a promising way of solving a variety of problems that firms traditionally solve internally. Many large firms reveal their internal knowledge in order to collaborate with external sources, especially when partner uncertainty and coordination costs are high and potential collaborators are not interested (Alexy et al., 2013).

An information system is considered as an enabler for open innovation in general and crowdsourcing in particular. However, Majchrzak and Malhotra (2013) argue that the information system is not just an enabler but also an integral part for finding results in crowdsourcing. Crowdsourcing is used for a wide range of purposes, as shown by the taxonomy proposed by Saxton et al. (2013). Crowdsourcing can also be used to incorporate internal stakeholders such as employees (Stieger et al., 2012). However, the real performance of the ideas generated by crowds lies in their market performance.

Studies have largely neglected the market performance of crowdsourcing ideas. However, some studies found that crowd-generated products have higher novelty and outperform professionally generated products on some market performance metrics (Whitla, 2009; Nishikawa et al., 2013). Using a unique longitudinal dataset of 922 organizations that responded to 105,127 suggestions from crowds and considering three different dimensions of distance (content, structural, and personal distance), a study by Piezunka and Dahlander (2015) found that these distances have independent negative effects on the likelihood of gaining attention. A fundamental issue related to crowdsourcing is motivation. Without motivation, no one engages in crowdsourcing. Crowdsourcing is used for variety of tasks (from very simple tasks to highly sophisticated tasks), and there are a wide range of motivational factors. Motivational factors include extrinsic motivations, such as money and user needs, as well as intrinsic motivations, such as altruism, fun, kinship, reputation, status, profession, personal identity, and reciprocity (Boudreau and Lakhani, 2009; Seidel and Langner, 2015). As a whole, crowdsourcing as a phenomenon is flourishing in various promising directions.

\subsubsection{Critiques of crowdsourcing}

Crowdsourcing has received increasing attention from scholars and practitioners. However, scholars have found deficiencies in crowdsourcing too. Bloodgood (2013) argues that solving problems leads to better performance but top managers are not tasked with problem solving. Their main aim is to maximize the wealth of firms. He points out that crowdsourcing seemingly does not increase the substantive performance of firms. Rosen (2011) identified four types of problems associated with the crowdsourcing concept: the quality of ideas, the 
lack of compensation, the lack of community among the crowd, and the lack of diversity among crowdsourcers. A key challenge of crowdsourcing lies in the quality of the ideas generated by the crowd. Ideas generated via crowdsourcing are diverse and sorting through these diverse ideas to find the best ideas is challenging (Roman, 2009). A large portion of ideas are irrelevant to a firm looking for valuable ideas (Whitla, 2009). Therefore, the help of experts is necessary in the idea selection process (Dokoupil, 2008).

Some popular ideas may not have quality and Belsky (2010) argues that crowds are amateurs who are prone to creating low-quality ideas compared to professional counterparts. Roman (2009) points out that crowdsourcing may not be useful for sophisticated problems where experts are essential. Crowds are poorly compensated, especially for microtasking. In an idea contest only the winner or winning group receives a reward (Hossain, 2012b). Moreover, it is difficult to engage experts in idea generation for a field as experts usually have high-paying careers (Rosen, 2011). Despite some criticisms, crowdsourcing is becoming significantly relevant for scholars and practitioners. Examples of the common implementation of crowdsourcing are described in the following section.

\subsubsection{Common implementations of crowdsourcing}

Crowdsourcing has a wide range of implementations. Examples of the most common implementation of crowdsourcing are idea contests (Bullinger et al., 2010), online communities (Füller et al., 2007), microtasking (Chiu et al., 2014), open-source software (von Hippel, 2003), and citizen science (Silvertown, 2009), among others. Idea contests have been facilitated by the development of information and communication technology (specifically high speed internet access) that allows individuals, firms, public organizations, and non-profit organizations to organize idea contests (Piller and Walcher, 2006). Online communities have emerged as a vibrant source of innovations and creativity (Dahlander et al., 2008; Martinez, 2015). The influence of the social network perspective is crucial in online communities. Chan et al. (2015) found that peerto-peer and peer-to-firm interactions with past ideation participation influence the likelihood of idea generation. Completing small parts of a large task by using a crowd is a new way to get many jobs done.

Microtasking can take place for tasks such as translation, transcription, research, and classification. However, a revolution in crowdsourcing is opensource software (Shah, 2006). Open-source software projects rely on thousands of volunteer software developers who contribute to developing open-source software that is freely available for anyone to use. The citizen science movement advances scientific knowledge, investigating scientific problems through the scientific community (Trumbull et al., 2000).

The use of crowdsourcing is encompassing many new directions. However, the three most common forms of the implementation of crowdsourcing (idea contests, idea generation by online communities, and microtasking) are be described in detail in the following sections. 


\subsubsection{Idea contests}

The online idea contest as a form of crowdsourcing is common for large organizations that can use their own crowdsourcing platform (Chesbrough, 2012) or intermediary platforms (Hossain, 2012b). Firms primarily use an idea contest as a mechanism to collect ideas for new products (Piller and Walcher 2006). Idea contests have been used for many centuries to solve specific problems and advance science and technology. The Internet, along with supporting tools, has brought a new dimension to idea contests. Large firms such as Cisco, General Electric, and IBM are heavily involved in idea contests. However, the use of an idea contest in place of conventional research techniques through online is a recently-emerged and a growing phenomenon (Schweitzer et al., 2012; Mortara et al., 2013).

In an online idea contest, organizations or individuals call on crowds to submit new ideas within a specific period of time, and the best ideas are selected and its ideator(s) rewarded. Poetz and Schreier (2012) demonstrated that crowds can outperform professionals in many levels of new product ideation. General Electric's Ecomagination contest, for example, has resulted in $\$ 140$ million investment in 23 ventures (Chesbrough, 2012). In 2007, Cisco initiated its first idea contest for network solutions with business plans. In five weeks, the initiative resulted in 2500 ideas from a crowd from 104 countries. After screening those ideas, 450 ideas were selected for the next phase and subsequently the best 12 ideas were presented to Cisco's top management. Finally, the idea presented by an ideator named Anna Gossen, along with her husband and a brother, won the top prize of $\$ 250,000$. Moreover, Anna was given a position in a business unit built based on her idea with a $\$ 10$ million investment from Cisco.

State organizations, such as NASA (King and Lakhani, 2013), and non-profit organizations, such as the X Prize Foundation (Wagner, 2011), are continuously organizing large-scale idea contests to find breakthrough innovations. Moreover, idea contests by intermediaries are a growing phenomenon. Many organizations use intermediary platforms so that they do not need to develop and learn the idea contest process. Some popular idea contest platforms are IdeaConnection, InnoCentive, PRESANS, NineSigma, and Ideaken (Huston and Sakkab, 2006; Jeppesen and Lakhani, 2010; Hossain, 2012b). These intermediary platforms host small to large-scale idea contests. NineSigma, for example, has a contest of CAD \$35 million, sponsored by the Climate Change and Emissions Management Corporation, to find the most innovative technologies to turn $\mathrm{CO} 2$ emissions into new carbon-based products and markets.

Moreover, an idea contest is also promising for the business-to-business context, especially for software development (Ågerfalk and Fitzgerald, 2008). An idea contest can be used for simple task such as graphic design, advertisement design, name and slogan design, and website design (Brabham, 2010; Zheng et al., 2011). In an idea contest, Mack and Landau (2015) found that successful participants have higher levels of domain-relevant skills and creativity-relevant processes than non-participants. A reward induces a higher number of submissions and a higher quality of submissions, and a high-quality crowd is less likely to submit tasks when a quality solution is already submitted (Liu et al., 2014). 


\subsubsection{Online community}

Ideation with collective intelligence is a way to get ideas from external sources. Crowds generate ideas as a community on online communities. However, ideas of this kind do not take much time and resources for a crowd to develop. Large firms such as Dell, IBM, Procter and Gamble, and Starbucks are using the online community to find valuable ideas from crowds (Lutz, 2011). IBM's Innovation Jam initiative, for example, brought over 46,000 ideas from 150,000 employees, family members, partners, clients, and university researchers from 104 countries (Bjelland and Wood, 2008). IBM engaged 60 researchers to sort the ideas generated through the Innovation Jam initiative (Birkinshaw et al., 2012). Thus, a significant amount of time and effort is necessary from experts to sort, score and give feedback on such a large number of ideas (Birkinshaw et al., 2012).

IdeaStorm and My Starbucks Idea are two prominent platforms (of Dell and Starbucks respectively) that generate ideas by continuously engaging external people (Di Gangi and Wasko, 2009; Bayus, 2013; Lee et al., 2014). Surowiecki (2005) claimed that a collective effort by the crowd is often better than reliance on a few experts for ideation, prediction, and decision-making. Understanding the behavior of crowds in order to share knowledge is pivotal for the success of crowdsourcing communities (Frey et al., 2011; Sun et al., 2012). In crowdsourcing communities, solutions are derived directly from the integrated contribution of heterogeneous contributors (Geiger and Schader, 2014). Crowdsourcing can be a better mechanism in place of internal sourcing for some problems, especially when it turns a distant search into a local search, thereby firms can gain numerous benefits (Afuah and Tucci, 2012). Bayus (2013) found that serial ideators are more likely to generate ideas that are valuable for firms to implement. However, diverse comments on ideas help to improve raw ideas into ideas valuable to the firm.

Community-based crowdsourcing platforms such as Wikipedia and YouTube are significantly affecting traditional firms and they emerged as a new organizational form (Levine and Prietula, 2014). Large firms struggle with their big data, which can be exposed to crowds who can quickly identify the possible use of a given dataset (Martinez and Walton, 2014). For instance, Bonabeau (2009) argues that a crowd can perform better than theorists can explain, especially for idea generation, but managers need to consider some key issues, such as the loss of control and balancing between diversity and expertise. A growing number of smartphones worldwide offer crowdsourcing applications, engaging a large crowd. Smartphones' capabilities-such as geolocation, light, movement, audio and visual sensors-offer many new, efficient ways to collect data (Chatzimilioudis et al., 2012). A crowd can accomplish some tasks not only with smartphones but also with simple mobile devices, as shown by Eagle (2009) and Gupta et al. (2012). Crowdsourcing is valuable for firms but the crowds may feel they are being exploited and cheated in crowdsourcing (Djelassi and Decoopman, 2013). For simple tasks, Shao et al. (2012) found that higher rewards, easier tasks, longer duration for idea generation, and lower competition intensity lead to a higher number of solvers, whereas higher rewards, longer duration for idea generation, and a higher difficulty level of tasks lead to the higher ability level of winners. 
On crowdsourcing platform, Huang et al. (2014) found that crowds are fast learners, coming up with promising ideas although their knowledge regarding the firm's cost structure was quite low. However, they found that firms' failure to distinguish between high- and low-potential ideas and between high- and low-ability ideators leads to a drop in the overall number of promising ideas.

\subsubsection{Microtasking}

Microtasking is an online labor market where requesters post jobs and workers choose which jobs to do for pay. It is defined as a system in which the crowd completes for a small part of a big task in order to get monetary or non-monetary rewards. Most of the studies on microtasking have focused on using a crowd as a source of data for experiments. Amazon's Mechanical Turk is a highly cited and successful microtasking platform (Mason and Suri, 2012). Many scholars are cynical about the quality of data that are received from the online labor market (Paolacci et al., 2010). However, studies found that the data obtained via the Mechanical Turk platform is as reliable as that of traditional methods, the cost is very low and the time required is minimal (Buhrmester et al., 2011). Microtasking platforms are considered a valuable source of data for reliable experiments (Berinsky et al., 2012; Crump et al., 2013). Microtasking platforms involve three types of actors: a project owner, a platform owner, and microworkers. The microtasking process has three main distinct phases: the evaluation phase, the task design phase, and the integration phase (Olsen and Carmel, 2013). CrowdSource and Microtask are two prominent microtasking platforms that are actively involved in transferring paper copies of documents into a digital format through crowdsourcing. Hence, they are adding value by helping to keep records of events that took place many years ago. 


\section{Method}

In this section, the research methods that are used in this dissertation are described. The overall research approach and type of methodology used in each substudy are explained here. Moreover, the sources of data, the data collection process, and research techniques are also provided in this section.

\subsection{Research approach}

The research approach of this dissertation consists of the systematic literature review method, qualitative method, and quantitative method. The systematic literature review method is used to identify appropriate studies and synthesize the knowledge of those studies in order to gain an idea of the state-of-the-art position of the research fields. Substudies 1, 2, 3, and 4 are based on systematic literature review. The qualitative method is used in substudies 5,6 , and 7 . Substudies 8 and 9 are based on the quantitative research method.

Three substudies with a qualitative research approach $(5,6$, and 7$)$, used three separate cases. Substudy 5 explored the Innovation Mill (IM) case. The IM worked as an intermediary matchmaker to transfer Nokia's non-core IATs to SMEs. In this substudy, interviews are conducted among different personnel such as the managers of IM, a director (tech out-licensing) of Nokia and four CEOs of startups. Substudy 6 explored the IdeaConnection case. The website of this online intermediary platform contains interviews with a large number of successful solvers. The interview texts from the IdeaConnection platform are used in the substudy. Moreover, substudy 7 used a non-profit organization called X Prize. This study used data and information from secondary sources.

The dissertation contains two substudies ( 8 and 9) that are based on a quantitative approach. Substudy 8 was conducted by extracting data from the IdeaStorm platform, a crowdsourcing platform administered by Dell. Crowds submit ideas on the platform and a platform management team implements ideas as per Dell's strategy. Necessary data related to each implemented idea is extracted by manually visiting and extracting it from each idea link. Using a similar research approach as is used in substudy 8, this dissertation also explored the crowdsourcing platform called My Starbucks Idea, administered by the Starbucks Corporation (substudy 9). The My Starbucks Idea platform contains all the ideas submitted on it by the crowd. Moreover, ideas are categorized with the following statuses: under review, reviewed, coming soon, and launched. The information on successfully launched ideas is used in the substudy 9. 


\subsection{Sources of data}

The sources of data are multiple. For substudies 1, 2, 3, and 4, the data and information consist of published articles. Substudy 5 uses interview data from Nokia, Tekes, and IM (an intermediary technology transferring platform), a journalist, and several CEOs of Finnish startups. Substudy 6 is based on data from a Canada-based open innovation intermediary platform called IdeaConnection. This substudy used the interview data of 82 successful solvers who had solved at least one problem by working in a group comprised of three to five members. Substudy 7 used data from an intermediary platform, called the $\mathrm{X}$ Prize Foundation that organizes mega competitions with rewards in the millions. Three competition cases organized by the $\mathrm{X}$ Prize Foundation are used as illustrations to show how breakthrough innovation can be made using a unique operational model.

Substudy 8 and substudy 9 use similar types of data. For substudy 8 , data are collected from IdeaStorm, which is an online idea platform of Dell. It uses the necessary and available data from 162 successful ideas from IdeaStorm. Similarly, data for substudy 9 were collected from My Starbucks Idea. Starbucks engages external individuals to get ideas to improve the products and services of Starbucks. Substudy 9 uses 320 successful ideas that have been submitted by individuals and implemented by Starbucks. Thus, the data for this dissertation were collected from a wide variety of sources.

\subsection{Data collection}

For four literature review substudies, the necessary articles were collected from published sources. For the three qualitative substudies, the triangulation approach was used in the data collection process. The reason for adopting the triangulation approach is that it increases the reliability of the data by using multiple data collection methods and sources (Mathison, 1988). Following the studies by Lewis (1998) and Flick (1992), interviews, secondary data, observations, and intuition are utilized in the qualitative substudies of the dissertation. For two quantitative substudies of the dissertation, data were collected from online crowdsourcing platforms by visiting each idea link.

\subsection{Research techniques}

Several research techniques are used in this dissertation. In substudies 1, 2, 3, and 4, the systematic literature review technique is used. Substudies 5 and 6 adopted the qualitative technique using interview data. Substudy 7 also adopted the qualitative technique. Both substudies 8 and 9 adopted quantitative techniques including regression, the Kruskal-Wallis test, the Mann-Whitney test, the ANOVA test, and independent sample $t$-tests. 


\subsection{Validity and reliability}

Validity and reliability are key requirements for every research study. Validity indicates how sound a research study is. Validity deals especially with the research design and the research methods. Validity is broadly classified into two categories: internal validity and external validity. Internal validity can be hampered, for example, by poor research design or by problems with the research instruments used. External validity concerns the extent to which the findings of a study can be generalized to other contexts (Lincoln and Guba, 1985; Yin, 2003). The findings of a study should be consistent over time and across research methods (Huberman, 1994). Reliability refers to the degree to which a research protocol produces stable results (Yin, 2003).

The concepts of validity and reliability are more used concerning quantitative research than concerning qualitative research. However, these concepts are highly relevant in both quantitative and qualitative research (Hammersley, 1987). In this dissertation, careful measures were taken in order to reach as high validity and reliability as possible. The validity and reliability of the substudies of the dissertation are discussed in the following.

The four first substudies are literature reviews. In order to increase the validity and reliability of these substudies, a systematic literature review approach was used. Moreover, other ways to increase the validity and reliability of these substudies were that the total number of articles included was high and that, within the article data bases used, all articles that fulfilled the selection criteria were included in the study. The selected article can be considered representative of all the articles that have been published in the field.

Substudies 5, 6, and 7 are qualitative research studies. Much attention was paid to selecting the most appropriate qualitative approaches to attain high validity and reliability. In addition, the triangulation technique was used in all these three substudies. Triangulation entails using parallel data from multiple sources and applying rich, robust, comprehensive, and well-developed research methods to corroborate the validity and reliability of a research study. In substudy 5, the interviews were recorded with due permission from the interviewees. The interviews were transcribed for analysis purposes. In substudy 6, a large number of interviews, along with adjunct secondary data, were used. As substudies 5 and 6 are based on single case analyses, one should exercise caution as regards to the generalizability of the results.

Substudies 8 and 9 are quantitative research studies. A large amount of data was gathered for these substudies from two popular crowdsourcing platforms. Appropriate statistical significance analyses were performed in order to ensure validity and reliability in these substudies. 


\section{Review of the results}

This dissertation demonstrates that the sourcing of innovations from external sources is essential for both large and small firms. Even though sourcing innovation from external agencies as a discipline has received significant attention from scholars and practitioners, there is the opportunity and necessity to study this phenomenon. The open innovation and crowdsourcing concepts have emerged to provide insights on external sourcing. With an extensive review of existing literature, substudies 1, 2, 3, and 4 have synthesized the existing knowledge and identified research gaps. Substudies 5 to 9 identified empirical findings on open innovation and crowdsourcing disciplines. The overall findings are as follows. Many innovations that are non-core to the incumbent large firms could be very good resources for others, especially for small firms. However, developing new types of policy and financing is essential for fostering the process of firms commercializing the non-core innovations of large firms. Open innovation can be used for competition-based breakthrough innovation with novel source of financial mechanism without huge investment. Engaging external individuals is useful for a firm. Monetary incentives are essential for sourcing high-end innovation from the outside. Monetary incentives are also necessary when intermediary platforms are used. On the contrary, no incentives, or non-monetary incentives, can be used when firms look for ideas that are not highly sophisticated and ideators do not need to devote a significant amount of time to ideation. The results of the substudies are as follows.

\subsection{A review of open innovation literature}

The first substudy is a systematic literature review on open innovation. Altogether 293 relevant articles were identified for statistical analysis. Additionally, contributory articles published between 2003 and June 2015 were included for content analysis. By using a large number of articles this substudy contributes in two ways. It sheds light on the overall development of the open innovation literature and highlights the findings of significant studies. It provides a detailed knowledge of the progress of open innovation literature.

By content analyses of selected academic articles on open innovation it points out the insights of the major conceptual, empirical, and review articles. The review of conceptual studies helps gather knowledge of the dominant concepts in the extant literature. The review of empirical studies revealed the major findings that exist in the extant literature. Furthermore, analyzing existing review articles helped gather knowledge of the state-of-the-art open innovation literature. Consequently, as a literature review article, the first substudy is positioned to find new evidence that is not explored by other literature review studies. The 
first substudy unveils the most influential articles, authors, and journals of the open innovation discipline. Moreover, it presents the geographical locations of influential articles and authors. Thus, it presents a new framework for open innovation research, it highlights the progress of current research, and it provides future research avenues.

\subsection{An analysis of open innovation literature}

The purpose of this substudy is to explore various patterns developed in open innovation literature including 411 articles published between 2003 and June 30, 2014. This substudy is based on dividing the total time period of the publications into three distinct periods: early (2003-2006), advanced (2007-2010), and recent (2011-2014). Classifying 411 articles in a range of key attributes, this substudy conducted a bibliometric analysis. Europe as a region of data source (61\%) was higher than all other regions put together. As a unit of analysis, firm level (65\%) accounted for more than all the other levels together. Qualitative studies were mostly case based and quantitative studies were largely based on survey and panel data. Regression was widely used as an analytical technique. US authors were dominant in the literature in the period studied. Recently, however, authors from the UK and Germany had leading positions. Germany was more dominant in the advanced period (2007-2010). Spain, the Netherlands, Italy, Belgium, Switzerland, Sweden, and Denmark were significantly represented in the open innovation literature. Spain and Belgium were not so visible in the early period but became highly noticeable in recent years, whereas both the Netherlands and Sweden were key players in all three periods. Some Asian countries such as Taiwan, South Korea, and China were absent in the early period and had little presence in the advanced period but had noticeable presence in the recent period. The majority of the authors in developing countries were located in China. Thus, it identified overlooked research topics and suggested embracing cross-continental collaboration and the diversity of research methods (beyond case study and survey methods, among others) in future studies.

\subsection{A review of open innovation in SMEs}

The third substudy synthesizes the existing literature on open innovation in SMEs. The main contribution of this substudy is the integration of the limited but scattered studies on open innovation in SMEs so that scholars can get an overall understanding of this research area. Based on a thematic analysis of the articles selected through a systematic search, this substudy found that a number of studies claimed that adopting open innovation improves SMEs' overall innovation performance. Moreover, unlike many other disciplines, scholars of North America have a limited contribution to the research area of open innovation in SMEs. European scholars, along with some scholars from Korea and China, have played a pivotal role in developing this research area. This substudy found that the number of articles published in top-tier journals is negligible. The extant literature comprises a large number of quantitative studies and the main sources of data of these studies are online surveys and panel data. The community innovation survey database is used in many highly regarded studies (see 
Laursen and Salter, 2006; Fu, 2012; Spithoven et al., 2013; Laursen and Salter, 2014).

\subsection{A review of crowdsourcing literature}

The fourth substudy explored the development of crowdsourcing literature. This substudy reviewed 346 articles on crowdsourcing that were collected from nine selected publishers. An additional 52 articles were extracted from other sources. Moreover, a range of highly cited articles were also included from various sources. Both statistical and content analyses were performed on these selected articles. This substudy found several valuable results regarding crowdsourcing literature. As per the Google Scholar citation count, ISI listed journal articles, non-ISI listed journal articles, and conference articles have almost the same contribution to crowdsourcing literature. Non-ISI listed journal articles played a major role in the initial theory development of crowdsourcing.

The number of articles by US scholars is almost same as the number of articles by scholars from all the European countries combined. On the other hand, scholars from developing countries were more active in conference articles than in journal articles. Top-tier journals have only engaged in publishing on crowdsourcing in the latter years. This substudy identified the major applications of crowdsourcing. Crowdsourcing is mainly applied in activities such as idea generation, microtasking, open-source software, public participation, citizen science, citizen journalism, and wikis. Crowdsourcing has much unused potential, and the use of crowdsourcing is increasing rapidly. Thus, this substudy explored the loci and foci of extant articles and the various applications of crowdsourcing.

Based on above four review substudies, a comprehensive knowledge on open innovation and crowdsourcing has been developed, and some research gaps for the empirical settings have been identified. The following five empirical substudies have attempted to narrow the research gaps that are highlighted in the above four review substudies.

\subsection{Transfer of non-core IATs}

The fifth substudy investigates how Nokia transferred its non-core IATs to Finnish SMEs through an intermediary organization with state financial support. This substudy illustrates how various actors in an ecosystem have successfully developed and embraced a new approach to appropriating the non-core IATs of Nokia Corporation. It explored the underlying ecosystem and analyzed actors and their roles in order to understand the challenges and achievements of the non-core IATs transfer process. Over a period of time, large firms acquire a pool of IATs that are misfits for internal use but which may turn out to be valuable for external firms. The lesson learned from Nokia's IATs transfer initiative provides opportunities for other large firms to successfully transfer their non-core IATs. 


\subsection{Motivations, challenges, and opportunities of solvers}

The sixth substudy identified the motivations, challenges, and opportunities of successful solvers who participate in virtual problem solving teams on an intermediary online open innovation platform. It provides insightful knowledge on problem solvers who solve problems in a team (typically consisting of three to five members) in an intermediary platform called IdeaConnection. The substudy found that the main motivations for solvers were money, learning, fun, a sense of achievement, passion, and networking. The challenges they face during online problem solving are as follows: difficulties in becoming a quick learner and team player, unclear or insufficient problem description, a lack of options for communication, the language barrier, different time zones, and difficulties finding suitable team members and framing the results. Despite many challenges, however, successful solvers can: diversify their knowledge, culture and thinking; acquire insights from other experts; gain the ability to work in a diverse environment; get opportunities to work after retirement; work from distant locations; and have a complementary source of earning.

\subsection{Competition-based breakthrough innovation}

The seventh substudy explored the X Prize Foundation, an intermediary nonprofit organization that organizes competitions for breakthrough innovation with the reward tag being in the millions (using funding sources such as insurance firms, philanthropists, and donations from large firms). Moreover, each competition of the X Prize Foundation lasts for several years so that participants can have enough time to come up with breakthrough innovations. This substudy shows how a non-profit organization organizes competitions for the advancement of science and technology. Analyzing the X Prize Foundation and its three successfully completed competitions, this substudy identified the challenges of competition-based breakthrough innovations and how to overcome them.

The main challenges for the foundation are as follows. The foundation has no budget of its own for prizes so managing funding from external sources is the only option and this is very challenging. Designing a competition for breakthrough innovation is also challenging. It took about a year to develop a set of rules that could be easily understood and verified, and the objective met with minimum cost. Each competition is designed in such a way so that participants need to invest significant time and effort to win. However, the solutions of an ongoing challenge may be found by others who are not associated the X Prize Foundation. For example, a competition called the Archon Genomics X Prize was cancelled on seeing that others had found a solution. Although mega competitions bring out advancements in technologies, those technologies may not get adequate support for commercialization. Competition-based innovation shifts the risks from organizers to contestants as only the winning team gets rewarded. It shows the potential of breakthrough innovation with unifying principles in place of modularity. Therefore, modularity may not be as important in acquiring innovation from external sources as some scholars advocate (see Staudenmayer et al., 2005; Schilling, 2000). 


\subsection{Ideation on the IdeaStorm platform}

The eighth substudy probed IdeaStorm - which is an online platform administered by Dell-in order to identify factors associated with idea selection and implementation through an online open innovation platform. This substudy found the following insights. Sole ideas get implemented quicker than ideas that are linked with other ideas on the platform. However, sole ideas take more time, receive more comments, and have higher points for successful implementation. Active ideators are not only prompt in idea submission, they contribute in other ways such as by commenting and voting.

This substudy found that only three percent of the submitted ideas get implemented, meaning the remaining $97 \%$ of ideas are not worthy of implementation as per Dell's strategy. Nevertheless, Dell gets opportunities to interact with customers, integrate marketing activities, and test its ideas and products. Thus, a large firms' online open innovation platforms are useful for their profitable growth.

\subsection{Ideation on the My Starbucks Idea platform}

This ninth substudy investigated the issues that are key for implementing the ideas proposed by crowds on Starbuck's online platform, called My Starbucks Idea. This substudy mainly followed the research technique used in the eighth substudy, which dealt with Dell's IdeaStorm platform. This substudy found that the ideas of product category get implemented easier than other categories, such as the experience and involvement categories. Only one out of 500 submitted ideas get implemented. Managers spend a huge amount of time throughout the process to pick out a tiny portion of implementable ideas from this large pool of ideas. This is a dilemma firms need to embrace and previous studies have pointed out this dilemma too (Di Gangi et al., 2010; Jouret, 2009; Bayus, 2013). The number of implemented ideas increases significantly at the early stage of the platform. At the mature stage, even though an increasing number of ideas are submitted, the implemented ideas are proportionately low. Among the three categories of ideas-product, experience, and involvement ideas-ideas of the product category are implemented with the lower values of some associated variables than that of the experience category, whereas the values in the involvement category are highest. Linked ideas need lower scores than sole ideas to get implemented. The chance that an idea to be implemented largely depends on the votes it receives and the points it earns. 


\section{Implications}

\subsection{Theoretical implications}

This dissertation revealed some key implications for theories on open innovation and crowdsourcing. From the four literature review substudies, it can be deduced that adopting open innovation and crowdsourcing helps firms to increase their innovation performance. Innovation performance should be measured in the commercial stage, especially considering the revenues or other values generated by each innovation or firm. However, open innovation and crowdsourcing concepts are typically analyzed in the development stage and their relevance in the commercial stage is very limitedly explored.

Open innovation is highly studied by European scholars and in the context of Europe. North America as a region is the second to Europe, followed by Asia (dominated by scholars from China). Some countries-such as Australia, Canada, India and Japan-are almost absent in open innovation literature. Open innovation is studied predominantly in disciplines such as management, operation research, and industrial engineering whereas it has received little attention from the scholars of disciplines such as economics and entrepreneurship. Open innovation in SMEs has received attention in recent years. Most of the articles on open innovation in SMEs are based on panel data from Europe and South Korea. Open innovation in SMEs has remained almost unexplored in the context of North America.

In crowdsourcing literature, however, scholars from the USA have the same impact as the scholars from all the European countries put together. Interestingly, conference articles outnumber journal articles in crowdsourcing literature. Crowdsourcing is considered a new industry and a source of earnings for various professionals such as the microtask workforce, designers, and innovators.

Firms are more active in the outside-in process than the inside-out process. The dissertation explored both the outside-in and inside-out processes of open innovation. Idea generation based on crowdsourcing, idea contests, and online communities are explored as part of the outside-in process. However, the inside-out process explored here is limited in non-core IATs. Interestingly, substudy 7 revealed a mode of open innovation that is different from the three modes illustrated in the extant literature. In this mode, knowledge neither inflows nor outflows from firms. Rather, it advances sciences by attempting to develop breakthrough innovations. 
The empirical findings of the dissertation are intriguing. Large firms can transfer non-core IATs to outside their boundaries to gain revenue or for philanthropic purposes. Philanthropic donations of non-core IATs may create an ecosystem that can directly/indirectly bring benefits for the parent firms. However, the number of studies on non-core IATs is very scarce (Anokhin et al., 2011; Carlsson et al., 2008; Gans and Stern, 2010). Thus, this dissertation increases understanding on various aspects of non-core IATs.

One stream of open innovation literature is online open innovation platforms. Although this dissertation, like some other studies (Antikainen and Vaataja, 2010; Frey et al., 2011), identified that money is an important incentive for crowds in intermediary open innovation platforms, other incentives-such as learning, fun, a sense of achievement, a passion for problem solving, and networking-play a significant role in crowds' engagement. It is found that prior knowledge of solvers on or around the field of the problem is key for a successful solution, even though previous studies found otherwise (Jeppesen and Lakhani, 2010). A team of three to five members who complement each other is an appropriate option to avoid high team heterogeneity (Girotra et al., 2010). A fundamental challenge for solvers while solving problems on online open innovation platforms is getting feedback from the problem seekers, especially when, as is often the case, seekers remain anonymous. Empirical evidence confirms that crowds outperform professionals in many levels of new product ideation. Idea competitions bring out more and better ideas at a lower cost per idea. Even though intellectual property is an important aspect of innovation, it is limitedly discussed in open innovation literature and almost undiscussed in crowdsourcing literature.

\subsection{Practical implications}

External innovation is increasingly gaining relevance and complementing internal innovation for large firms. In high-end challenges, firms need to define a problem very clearly, including the intended use of the solutions, so that solvers can easily understand the context of the problem. Large firms can use their own online platforms to find solutions from external experts. However, firms mostly use their own online platforms for simple ideation or occasionally for grand challenges. Therefore, large firms underuse online platforms for innovations. Managers consider intellectual property as a pressing dilemma in adopting open innovation and crowdsourcing. A deterrent for outside-in open innovation is the NIH syndrome (Lichtenthaler and Ernst, 2006; Kathoefer and Leker, 2012).

Open innovation platforms provide opportunities to tap knowledge from the outside-the-box thinking of unknown experts dispersed worldwide, including retired scientists who otherwise remained unused. Yet, managers do not use online open innovation platforms to their full extent. They find it difficult to balance between open innovation and closed innovation in various contexts. Moreover, there are no well-recognized measurement scales to understand the benefits of open innovation in practice. Open innovation in SMEs has been limitedly explored. Within the limited pool of scattered and diverse studies, the results are partly conflicting. Thus, managers, particularly of SMEs, do not have 
sufficient understanding about the importance of open innovation in their organizational contexts. Firms, small or large, can use crowdsourcing platforms for ideas by organizing idea contests or ideation with collective intelligence. An idea contest is appropriate for high-end solutions and ideation with collective intelligence is appropriate for simple ideas. It is increasingly becoming necessary for managers to understand various crowdsourcing modes so that they can reap value from crowdsourcing.

Large firms do not care enough for their non-core IATs, even though there is potential for gaining values from their IATs. This dissertation demonstrates that various actors in an ecosystem can successfully develop and embrace a new way to deal with the non-core IATs of a large firm. Donating non-core IATs was beneficial for firms in the USA as they used to get tax benefits on valuation. Recently, the tax benefits have been withdrawn in the USA. However, firms can transfer their IATs in various modes and still get at least some non-monetary benefits (if not monetary benefits).

Firms get excessive solutions when they use an idea contest on intermediary open innovation platforms. The reason is that firms pay for one solution but numerous solutions are submitted by various individuals and teams. Thus, firms acquire a huge number of IATs not only from internal sources but also from external sources. Hence, increasing exploration of the effective use of those IATs is important for firms.

Instead of spending a huge amount on R\&D, firms can collaborate with other firms that already have innovations but are unable to commercialize them. Moreover, firms can acquire technologies from other sources. For example, the $\mathrm{X}$ Prize Foundation's mega contests, with millions of prize money, bring breakthrough innovations that can be commercialized by other firms as most of the innovation teams of the $\mathrm{X}$ Prize Foundation do not have adequate resources to scale up their innovations.

By using their own crowdsourcing platforms large firms can not only find simple, intriguing ideas but also keep a continuous connection with their customers. Moreover, crowdsourcing platforms can be used for various purposes, such as marketing, integrated communications, and feedback, among others. 


\section{Limitations and future research direc- tions}

\subsection{Limitations}

There are several limitations in this study. First, the study considered successful cases of open innovation and crowdsourcing. Second, how successful the ideas that are generated from external sources in the commercial stage are, more precisely in terms of revenues, has not been explored. Third, large firms transfer their non-core IATs to external entities such as SMEs with support from state funding agencies. Whether those non-core IATs can be commercialized without state support and with other options, such as venture capital and joint venture, has not been explored. Fourth, some data sets were collected from the online platforms as recorded there. Hence, the veracity of those datasets lies on the platform managers.

\subsection{Future research directions}

This dissertation has explored various facets of open innovation and crowdsourcing. At the same time, it could not explore some interesting avenues. It explored the research, development, and transfer stages of ideas, technologies, and innovations. How innovations performance in the commercial stage would be very interesting to consider in future research. Linking open innovation and crowdsourcing with other established theories of management, economics, and entrepreneurship is necessary. Innovation performance under the open innovation concept is not adequately tested yet. A large number of studies are based on successful case illustrations (Tucci et al., 2016). Moreover, many scholars demonstrate the benefits of open innovation and encourage firms to embrace open innovation to improve their innovation performance. The claim that firms are increasingly adopting open innovation is still mostly anecdotal (Cricelli et al., 2015). Hence, more empirical studies with large samples and geographical consideration are essential.

Even though there are three modes of open innovation (outside-in, inside-out, and coupled open innovation) in the literature, this dissertation revealed another mode that does not fit into any of these modes. Hence, scholars need to expand the modes to accommodate this new mode that we witnessed in the case of the X Prize Foundation. Rigorous empirical studies to understand how firms are adopting and benefiting from the open innovation paradigm in practice is crucial. Longitudinal studies can be useful to measure the costs and benefits of adopting open innovation throughout the entire life cycle of a product. Most of 
the studies on open innovation set at the firm level. To broaden knowledge of open innovation in various contexts, empirical studies on the applicability of open innovation at the industry, national, regional, and global levels are essential.

When a firm should consider external sources in place of internal sources is limitedly tested in empirically settings. Hence, firms struggle as to when and how to consider open innovation in their innovation strategy. Most of studies illustrated the success of open innovation at the level of large firms. Open innovation is limitedly explored in the context of developing countries. Moreover, some innovative countries, such as Japan and Australia, remain unexplored. The above issues are important to consider for future exploration on open innovation and crowdsourcing.

Studies on open innovation in SMEs are limitedly explored, even though scholars argue that open innovation is beneficial for SMEs. Although large firms tend to collaborate with other firms, suppliers, customers, and even competitors, studies found that SMEs prefer to collaborate with suppliers over customers. However, the underpinning reason for SMEs' collaborative behavior is limitedly known.

Crowdsourcing literature is enriched largely by non-ISI-listed journal articles and conference proceedings, whereas ISI-listed journal articles are considered higher in quality than those of other categories. Even though intellectual property rights (IPRs) is a key issue related with innovation, crowdsourcing literature encompasses limited discussion on it. Exploring crowdsourcing to relating it to IPRs is important for enriching crowdsourcing literature.

In the crowdsourcing platforms of large firms, ideas are developed in online community through discussion, voting, and comments. In this process, firms may get valuable ideas without offering any reward. However, studies show that only a tiny portion of the submitted ideas get implemented. Hence, it would be interesting to understand how firms can drop unpromising ideas at an early stage so that crowd can concentrate heavily on a few highly promising ideas. Thus, firms need to use fewer workforce and less time and resources for screening the submitted ideas. 


\section{Conclusion}

This dissertation demonstrates that firms may acquire ideas, technologies, and innovations from external sources, not only to complement internal sources but also to get novel ways for sourcing valuable knowledge from outside their boundaries. Firms can develop their own platforms and invite external people to provide solutions. Depending on the level of complexity, they can offer rewards for a successful solution. Firms can acquire simple solutions without providing monetary incentives, as is the case with Starbucks' My Starbucks Idea and Dell's IdeaStorm. For highly sophisticated solutions, monetary rewards are essential, as with the X Prize case explored in this dissertation. Monetary reward is widely prevalent when intermediary platforms are used to find solutions from outside, as with the IdeaConnection platform case; all problems are designed with certain rewards for the successful solvers. Intermediary platforms are useful when solution-seeking firms want to remain anonymous. When the solution seekers are anonymous, a fundamental challenge for solvers is to get the context of what purpose a solution will be used for. Hence, on many occasions, solvers need to develop several solutions for a particular problem to increase their chance of winning.

For a long time firms kept their non-core IATs on their shelves for future use. However, most of those non-core IATs perish eventually. Firms have started appropriating from the IATs that cannot be used internally but that have value in external use. New ways of funding idea contests are emerging. Studies may probe the pros and cons of those funding options and seek more options to fund idea challenges. Firms can directly engage in taking their non-core IATs outside, or they can use intermediaries who will find matches for IATs. Intermediaries get a commission on each transfer of a non-core IAT. Thus, firms can embrace open innovation with outside-in, inside-out open innovation and other modes of open innovation and crowdsourcing for the advancement of innovations. 


\section{References}

Afuah, A., \& Tucci, C. L. (2012). Crowdsourcing as a solution to distant search. Academy of Management Review, 37(3), 355-375.

Ågerfalk, P. J., \& Fitzgerald, B. (2008). Outsourcing to an unknown workforce: exploring open sourcing as a global sourcing strategy. MIS Quarterly, 385-409.

Almirall, E., \& Casadesus-Masanell, R. (2010). Open versus closed innovation: A model of discovery and divergence. Academy of Management Review, 35(1), 27-47.

Alexy, O., George, G., \& Salter, A. J. (2013). Cui bono? The selective revealing of knowledge and its implications for innovative activity. Academy of Management Review, 38(2), 270-291.

Anokhin, S., Wincent, J., \& Frishammar, J. (2011). A conceptual framework for misfit technology commercialization. Technological Forecasting and Social Change, $78(6), 1060-1071$.

Antikainen, M. J., \& Vaataja, H. K. (2010). Rewarding in open innovation communitieshow to motivate members. International Journal of Entrepreneurship and Innovation Management, 11(4), 440-456.

Baldwin, C. Y., \& Henkel, J. (2015). Modularity and intellectual property protection. Strategic Management Journal, 36(11), 1637-1655.

Bayus, B. L. (2013). Crowdsourcing new product ideas over time: an analysis of the Dell Ideastorm community. Management Science, 59, 226-244.

Berinsky, A. J., Huber, G. A., \& Lenz, G. S. (2012). Evaluating online labor markets for experimental research: Amazon.com's Mechanical Turk. Political Analysis, 2O(3), 351-368.

Bianchi, M., Campodall'Orto, S., Frattini, F., \& Vercesi, P. (2010). Enabling open innovation in small-and medium-sized enterprises: how to find alternative applications for your technologies. $R \& D$ Management, $40(4), 414-431$.

Bjelland, O. M., \& Wood, R. C. (2008). An inside view of IBM's 'Innovation Jam'. MIT Sloan Management Review, 5o(1), 32-40.

Bloodgood, J. (2013). Crowdsourcing: Useful for problem solving, but what about value capture?. Academy of Management Review, 38(3), 455-457.

Bogers, M., Afuah, A., \& Bastian, B. (2010). Users as innovators: A review, critique, and future research directions. Journal of Management, 36(4), 857-875.

Bonabeau, E. (2009). Decisions 2.0: The power of collective intelligence. MIT Sloan Management Review, 5o(2), 45-52.

Boudreau, K., \& Lakhani, K. (2009). How to manage outside innovation. MIT Sloan Management Review, 5o(4), 69-76.

Boudreau, K. J., \& Lakhani, K. R. (2013). Using the crowd as an innovation partner. Harvard Business Review, 91(4), 60-69.

Birkinshaw, J., Bouquet, C., \& Barsoux, J. L. (2012). The 5 myths of innovation. MIT Sloan Management Review, 52(2), 42-50.

Brabham, D. C. (2008). Crowdsourcing as a model for problem solving an introduction and cases. Convergence: The International Journal of Research into New Media Technologies, 14(1), 75-90. 
Brabham, D. C. (2010). Moving the crowd at Threadless: Motivations for participation in a crowdsourcing application. Information, Communication \& Society,13(8), 1122-1145.

Buhrmester, M., Kwang, T., \& Gosling, S. D. (2011). Amazon's Mechanical Turk a new source of inexpensive, yet high-quality, data?. Perspectives on Psychological Science, 6(1), 3-5

Bullinger, A. C., Neyer, A. K., Rass, M., \& Moeslein, K. M. (2010). Community-based innovation contests: Where competition meets cooperation. Creativity and Innovation Management, 19(3), 290-303.

Bullinger, A. C., \& Moeslein, K. (2010). Innovation contests-where are we?. Innovation, 8, 1-2010.

Carlsson, B., Dumitriu, M., Glass, J. T., Nard, C. A., \& Barrett, R. (2008). Intellectual property (IP) management: organizational processes and structures, and the role of IP donations. The Journal of Technology Transfer, 33(6), 549-559.

Chan, K. W., Li, S. Y., \& Zhu, J. J. (2015). Fostering customer ideation in crowdsourcing community: the role of peer-to-peer and peer-to-firm interactions. Journal of Interactive Marketing, 31, 42-62.

Chatzimilioudis, G., Konstantinidis, A., Laoudias, C., \& Zeinalipour-Yazti, D. (2012). Crowdsourcing with smartphones. Internet Computing, IEEE, 16(5), 36-44.

Chen, Y., Vanhaverbeke, W., \& Du, J. (2015). The interaction between internal R\&D and different types of external knowledge sourcing: an empirical study of Chinese innovative firms. $R \& D$ Management (in press).

Chesbrough, H., \& Bogers, M. (2014). Explicating open innovation: clarifying an emerging paradigm for understanding innovation. New Frontiers in Open Innovation. Oxford: Oxford University Press, United Kingdom, 3-28.

Chesbrough, H., \& Crowther, A. K. (2006). Beyond high tech: early adopters of open innovation in other industries. $R \& D$ Management, 36(3), 229-236.

Chesbrough, H., \& Di Minin, A. (2014). Open social innovation. New Frontiers in Open Innovation, 169-188.

Chesbrough, H. W. (2003). Open innovation: The new imperative for creating and profiting from technology. Harvard Business Press.

Chesbrough, H. (2010). Open services innovation: Rethinking your business to grow and compete in a new era. John Wiley \& Sons.

Chesbrough, H. (2011). Bringing open innovation to services. MIT Sloan Management Review, 52(2), 85-90.

Chesbrough, H. (2012). GE's ecomagination challenge: An experiment in open innovation. California Management Review, 54(3), 140-154.

Chiaroni, D., Chiesa, V., \& Frattini, F. (2010). Unravelling the process from Closed to Open Innovation: evidence from mature, asset-intensive industries. $R \& D$ Management, 40(3), 222-245.

Chiu, C. M., Liang, T. P., \& Turban, E. (2014). What can crowdsourcing do for decision support?. Decision Support Systems, 65, 40-49.

Cricelli, L., Greco, M., \& Grimaldi, M. (2015). Assessing the open innovation trends by means of the eurostat community innovation survey. International Journal of Innovation Management, 1650039.

Crump, M. J., McDonnell, J. V., \& Gureckis, T. M. (2013). Evaluating Amazon's Mechanical Turk as a tool for experimental behavioral research. PloS one, 8(3), 1-18.

Dahlander, L., Frederiksen, L., \& Rullani, F. (2008). Online communities and open innovation. Industry and Innovation, 15(2), 115-123.

Dahlander, L., \& Gann, D. M. (2010). How open is innovation?. Research Policy, 39(6), 699-709.

Di Gangi, P. M., Wasko, M. \& Hooker, R. (2010). Getting customers' ideas to work for you: learning from dell how to succeed with online user innovation communities. MIS Quarterly Executive, 9, 213-228.

Di Gangi, P. M., \& Wasko, M. (2009). Steal my idea! Organizational adoption of user innovations from a user innovation community: A case study of Dell IdeaStorm. Decision Support Systems, 48(1), 303-312. 
Djelassi, S., \& Decoopman, I. (2013). Customers' participation in product development through crowdsourcing: Issues and implications. Industrial Marketing Management, 42(5), 683-692.

Dokoupil, T. (2008). Revenge of the experts. Newsweek Web Exclusive, (6), 5.

Dushnitsky, G., \& Klueter, T. (2011). Is there an eBay for ideas? Insights from online knowledge marketplaces. European Management Review, 8(1), 17-32.

Eagle, N. (2009). txteagle: Mobile crowdsourcing. In Internationalization, Design and Global Development (pp. 447-456). Springer Berlin Heidelberg.

Ebner, W., Leimeister, J. M., \& Krcmar, H. (2009). Community engineering for innovations: the ideas competition as a method to nurture a virtual community for innovations. R\&D Management, 39(4), 342-356.

Elmquist, M., Fredberg, T., \& Ollila, S. (2009). Exploring the field of open innovation. European Journal of Innovation Management, 12(3), 326-345.

Enkel, E., Gassmann, O., \& Chesbrough, H. (2009). Open R\&D and open innovation: exploring the phenomenon. R\&D Management, 39(4), 311-316.

Enkel, E., \& Gassmann, O. (2010). Creative imitation: exploring the case of cross - industry innovation. $R \& D$ Management, 4O(3), 256-270.

Estellés-Arolas, E., \& González-Ladrón-de-Guevara, F. (2012). Towards an integrated crowdsourcing definition. Journal of Information Science, 38(2), 189-200.

Fabrizio, K. R. (2009). Absorptive capacity and the search for innovation. Research Policy, 38(2), 255-267.

Flick, U. (1992). Triangulation revisited: strategy of validation or alternative?. Journal for the Theory of Social Behaviour, 22(2), 175-197.

Frey, K., Lüthje, C., \& Haag, S. (2011). Whom should firms attract to open innovation platforms? The role of knowledge diversity and motivation. Long Range Planning, 44(5), 397-420.

Füller, J., Jawecki, G., \& Mühlbacher, H. (2007). Innovation creation by online basketball communities. Journal of Business Research, 6o(1), 60-71.

Füller, J. (2010). Refining virtual co-creation from a consumer perspective. California Management Review, 52(2), 98-122.

Gans, J., \& Stern, S. (2010). Is there a market for ideas?. Industrial and Corporate Change, 19(3), 805-837.

Geiger, D., \& Schader, M. (2014). Personalized task recommendation in crowdsourcing information systems-current state of the art. Decision Support Systems, 65, 3-16.

Gianiodis, P. T., Ettlie, J. E., \& Urbina, J. J. (2014). Open service innovation in the global banking industry: Inside-out versus outside-in strategies. Academy of Management Perspectives, 28(1), 76-91.

Giannopoulou, E., Yström, A., Ollila, S., Fredberg, T., \& Elmquist, M. (2010). Implications of openness: A study into (all) the growing literature on open innovation. Journal of Technology Management \& Innovation, 5(3), 162-180.

Girotra, K., Terwiesch, C., \& Ulrich, K. T. (2010). Idea generation and the quality of the best idea. Management Science, 56(4), 591-605.

Grier, D. A. (2011). Not for all markets. Computer, 5(44), 6-8.

Grimpe, C., \& Sofka, W. (2009). Search patterns and absorptive capacity: Low-and hightechnology sectors in European countries. Research Policy, 38(3), 495-506.

Groen, A. J., \& Linton, J. D. (2010). Is open innovation a field of study or a communication barrier to theory development?. Technovation, $30(11), 554$.

Gruber, M., \& Henkel, J. (2006). New ventures based on open innovation-an empirical analysis of start-up firms in embedded Linux. International Journal of Technology Management, 33(4), 356-372.

Gupta, A., Thies, W., Cutrell, E., \& Balakrishnan, R. (2012, May). mClerk: enabling mobile crowdsourcing in developing regions. In Proceedings of the SIGCHI Conference on Human Factors in Computing Systems (pp. 1843-1852). ACM.

Hammersley, M. (1987). Some notes on the terms 'validity' and 'reliability'. British Educational Research Journal, 13(1), 73-82. 
Henkel, J., Schöberl, S., \& Alexy, O. (2014). The emergence of openness: How and why firms adopt selective revealing in open innovation. Research Policy, 43(5), 879-890.

Henkel, J. (2006). Selective revealing in open innovation processes: The case of embedded Linux. Research Policy, 35(7), 953-969.

Hienerth, C. (2006). The commercialization of user innovations: the development of the rodeo kayak industry. $R \& D$ Management, 36(3), 273-294.

Hossain, M., \& Anees-ur-Rehman, M. (2016). Open innovation: An analysis of twelve years of research. Strategic Outsourcing: An International Journal, 9(1), 22-37.

Hossain, M., Islam, K. M. Z., Sayeed, M. \& Kauranen, I. (2016). A comprehensive review of open innovation literature. Journal of Science and Technology Policy Management, $7(1), 2-25$.

Hossain, M., \& Islam, K.Z. (2015a). Ideation through online open innovation platform: Dell IdeaStorm, Journal of the Knowledge Economy, 6(3), 611-624.

Hossain, M., \& Islam, K. M. (2015b). Generating ideas on online platforms: A case study of "My Starbucks Idea”, Arab Economic and Business Journal, 1O(2), 102-111.

Hossain, M., \& Kauranen, I. (2014). Competition-based innovation: The case of the X Prize Foundation. Journal of Organization Design, 3(3), 46-52.

Hossain, M., \& Kauranen, I. (2015). Crowdsourcing: A comprehensive literature review. Strategic Outsourcing: An International Journal, 8(1), 2-22.

Hossain, M. \& Kauranen, I (2016). Open innovation in SMEs: A systematic literature review. Journal of Strategy and Management, 9(1), 58-73.

Hossain, M. (2012a). Open innovation mill: Utilization of Nokia's non-core ideas. Procedia-Social and Behavioral Sciences, 58, 765-773.

Hossain, M. (2012b). Performance and potential of open innovation intermediaries. Procedia-Social and Behavioral Sciences, 58, 754-764.

Hossain, M. (2013). Open innovation: so far and a way forward. World Journal of Science, Technology and Sustainable Development, 1O(1), 30-41.

Howe, J. (2006). The rise of crowdsourcing. Wired Magazine, 14(6), 1-4.

Huang, Y., Vir Singh, P., \& Srinivasan, K. (2014). Crowdsourcing new product ideas under consumer learning. Management Science, 6o(9), 2138-2159.

Huizingh, E. K. (2011). Open innovation: State of the art and future perspectives. Technovation, 31(1), 2-9.

Huston, L., \& Sakkab, N. (2006). Connect and develop. Harvard Business Review, 84(3), 58-66.

Inauen, M., \& Schenker-Wicki, A. (2011). The impact of outside-in open innovation on innovation performance. European Journal of Innovation Management, 14(4), 496-520.

Jeppesen, L. B., \& Lakhani, K. R. (2010). Marginality and problem-solving effectiveness in broadcast search. Organization Science, 21(5), 1016-1033.

Johannsson, M., Wen, A., Kraetzig, B., Cohen, D., Liu, D., Liu, H., ... \& Zhao, Z. (2015). Space and open innovation: Potential, limitations and conditions of success. Acta Astronautica. 115, 173-184.

Jouret, G. (2009). Inside Cisco's search for the next big idea. Harvard Business Review, $87,43-45$.

Kathoefer, D. G., \& Leker, J. (2012). Knowledge transfer in academia: an exploratory study on the Not-Invented-Here Syndrome. The Journal of Technology Transfer, 37(5), 658-675.

Katz, R., \& Allen, T. J. (1982). Investigating the Not Invented Here (NIH) syndrome: A look at the performance, tenure, and communication patterns of $50 \mathrm{R} \& \mathrm{D}$ Project Groups. R\&D Management, 12(1), 7-20.

King, A., \& Lakhani, K. R. (2013). Using open innovation to identify the best ideas. MIT Sloan Management Review, 55(1), 41-48.

Kleemann, F., \& Voß, G. G. (2008). Un(der) paid Innovators: The commercial utilization of consumer work through crowdsourcing. Science, Technology \& Innovation Studies, 4(1), 5-26. 
Laursen, K., \& Salter, A. (2006). Open for innovation: the role of openness in explaining innovation performance among UK manufacturing firms. Strategic Management Journal, 27(2), 131-150.

Laursen, K., \& Salter, A. J. (2014). The paradox of openness: Appropriability, external search and collaboration. Research Policy, 43(5), 867-878.

Lee, H., Han, J., \& Suh, Y. (2014). Gift or threat? An examination of voice of the customer: The case of MyStarbucksIdea.com. Electronic Commerce Research and Applications, 13(3), 205-219.

Lee, S., Park, G., Yoon, B., \& Park, J. (2010). Open innovation in SMEs-An intermediated network model. Research Policy, 39(2), 290-300.

Lettl, C., Herstatt, C., \& Gemuenden, H. G. (2006). Users' contributions to radical innovation: evidence from four cases in the field of medical equipment technology. $R \& D$ Management, 36(3), 251-272.

Levine, S. S., \& Prietula, M. J. (2014). Open collaboration for innovation: Principles and performance. Organization Science, 25(5), 1414-1433.

Lewis, M. W. (1998). Iterative triangulation: a theory development process using existing case studies. Journal of Operations Management, 16(4), 455-469.

Lichtenthaler, U., \& Ernst, H. (2006). Attitudes to externally organising knowledge management tasks: a review, reconsideration and extension of the NIH syndrome. R\&D Management, 36(4), 367-386.

Lichtenthaler, U., \& Lichtenthaler, E. (2010). Technology transfer across organizational boundaries: absorptive capacity and desorptive capacity. California Management Review, 53(1), 154-170.

Lichtenthaler, U. (2009). Outbound open innovation and its effect on firm performance: examining environmental influences. R\&D Management, 39(4), 317-330.

Lichtenthaler, U. (2011). Open innovation: Past research, current debates, and future directions. The Academy of Management Perspectives, 25(1), 75-93.

Lichtenthaler, U., \& Ernst, H. (2007). External technology commercialization in large firms: results of a quantitative benchmarking study. $R \& D$ Management, 37(5), 383397.

Lim, K., Chesbrough, H., \& Ruan, Y. (2010). Open innovation and patterns of R\&D competition. International Journal of Technology Management, 52(3/4), 295-321.

Lincoln, Y. S., \& Guba, E. G. (1985). Naturalistic inquiry, 75, Sage publications, USA.

Liu, T. X., Yang, J., Adamic, L. A., \& Chen, Y. (2014). Crowdsourcing with all-pay auctions: a field experiment on Taskcn. Management Science, 6o(8), 2020-2037.

Lopez-Vega, H., Tell, F., \& Vanhaverbeke, W. (2016). Where and how to search? Search paths in open innovation. Research Policy, 45(1), 125-136.

Loren, J. (2011). 'What is Open Innovation?. A guide to Open Innovation and Crowdsourcing: Advice from leading Experts, 1st edn., edited by Paul Sloane, 5-14.

Lutz, R. J. (2011). Marketing Scholarship 2.o. Journal of Marketing, 75(4), 225-234.

Mack, T., \& Landau, C. (2015). Winners, losers, and deniers: Self-selection in crowd innovation contests and the roles of motivation, creativity, and skills. Journal of Engineering and Technology Management, 37, 52-64.

Majchrzak, A., \& Malhotra, A. (2013). Towards an information systems perspective and research agenda on crowdsourcing for innovation. The Journal of Strategic Information Systems, 22(4), 257-268.

Marjanovic, S., Fry, C., \& Chataway, J. (2012). Crowdsourcing based business models: In search of evidence for innovation 2.o. Science and Public Policy, 39(3), 318-332.

Martinez, M. G., \& Walton, B. (2014). The wisdom of crowds: The potential of online communities as a tool for data analysis. Technovation, 34(4), 203-214.

Martinez, M. G. (2015). Solver engagement in knowledge sharing in crowdsourcing communities: Exploring the link to creativity. Research Policy, 44(8), 1419-1430.

Mason, W., \& Suri, S. (2012). Conducting behavioral research on Amazon's Mechanical Turk. Behavior Research Methods, 44(1), 1-23.

Mathison, S. (1988). Why triangulate?. Educational Researcher, 17(2), 13-17. 
Miles, M. B., \& Huberman, A. M. (1994). Qualitative data analysis: An expanded sourcebook, 2nd edn, Sage publications.

Mina, A., Bascavusoglu-Moreau, E., \& Hughes, A. (2014). Open service innovation and the firm's search for external knowledge. Research Policy, 43(5), 853-866.

Montelisciani, G., Gabelloni, D., Tazzini, G., \& Fantoni, G. (2014). Skills and wills: the keys to identify the right team in collaborative innovation platforms. Technology Analysis \& Strategic Management, 26(6), 687-702.

Mortara, L., Ford, S. J., \& Jaeger, M. (2013). Idea Competitions under scrutiny: Acquisition, intelligence or public relations mechanism?. Technological Forecasting and Social Change, $80(8), 1563-1578$.

Mortara, L., \& Minshall, T. (2011). How do large multinational companies implement open innovation?. Technovation, 31(10), 586-597.

Mowery, D. C. (2009). Plus ca change: Industrial R\&D in the "third industrial revolution". Industrial and Corporate Change, 18(1), 1-50.

Nishikawa, H., Schreier, M., \& Ogawa, S. (2013). User-generated versus designer-generated products: A performance assessment at Muji. International Journal of Research in Marketing, 3O(2), 160-167.

Oliver, A., Bascavusoglu-Moreau, E., \& Salter, A. (2016). Toward an aspirational-level theory of open innovation. Industrial and Corporate Change. 25(2), 289-306.

Olsen, T., \& Carmel, E. (2013). The process of atomization of business tasks for crowdsourcing. Strategic Outsourcing: An International Journal, 6(3). DOI: http://dx.doi.org/10.1108/SO-10-2013-0019.

Paolacci, G., Chandler, J., \& Ipeirotis, P. G. (2010). Running experiments on amazon Mechanical Turk. Judgment and Decision Making, 5(5), 411-419.

Parida, V., Westerberg, M., \& Frishammar, J. (2012). Inbound open innovation activities in high-tech SMEs: the impact on innovation performance. Journal of Small Business Management, 5O(2), 283-309.

Perkmann, M., \& Walsh, K. (2007). University-industry relationships and open innovation: Towards a research agenda. International Journal of Management Reviews, 9(4), 259-280.

Piezunka, H., \& Dahlander, L. (2015). Distant search, narrow attention: how crowding alters organizations' filtering of suggestions in crowdsourcing. Academy of Management Journal, 58(3), 856-880.

Piller, F. T., \& Walcher, D. (2006). Toolkits for idea competitions: a novel method to integrate users in new product development. R\&D Management, 36(3), 307-318.

Poetz, M. K., \& Schreier, M. (2012). The value of crowdsourcing: can users really compete with professionals in generating new product ideas?. Journal of Product Innovation Management, 29(2), 245-256.

Porta, M., House, B., Buckley, L., \& Blitz, A. (2008). Value 2.0: eight new rules for creating and capturing value from innovative technologies. Strategy \& Leadership, 36(4), 10-18.

Prahalad, C. K., \& Ramaswamy, V. (2004). Co-creation experiences: The next practice in value creation. Journal of Interactive Marketing, 18(3), 5-14.

Ribiere, V. M., \& Tuggle, F. D. (2010). Fostering innovation with KM 2.o. Vine, 4O(1), 90-101.

Rohrbeck, R., Hölzle, K., \& Gemünden, H. G. (2009). Opening up for competitive advantage-How Deutsche Telekom creates an open innovation ecosystem. R\&D Management, 39(4), 420-430.

Roman, D. (2009). Crowdsourcing and the question of expertise. Communications of the ACM, 52(12), 12.

Rosen, P. A. (2011). Crowdsourcing lessons for organizations. Journal of Decision Systems, $20(3), 309-324$.

Sawhney, M., \& Prandelli, E. (2000). Managing distributed innovation in turbulent markets. California Management Review, 42(4), 24-54.

Saxton, G. D., Oh, O., \& Kishore, R. (2013). Rules of crowdsourcing: Models, issues, and systems of control. Information Systems Management, 3o(1), 2-20. 
Schiele, H. (2010). Early supplier integration: the dual role of purchasing in new product development. R\&D Management, $40(2), 138-153$.

Schilling, M. A. (2000). Toward a general modular systems theory and its application to interfirm product modularity. Academy of Management Review, 25(2), 312-334.

Schroll, A., \& Mild, A. (2012). A critical review of empirical research on open innovation adoption. Journal für Betriebswirtschaft, 62(2), 85-118.

Schweitzer, F. M., Buchinger, W., Gassmann, O., \& Obrist, M. (2012). Crowdsourcing: Leveraging innovation through online idea competitions. Research-Technology Management, 55(3), 32-38.

Seidel, V. P., \& Langner, B. (2015). Using an online community for vehicle design: project variety and motivations to participate. Industrial and Corporate Change, 24(3), 635-653.

Shah, S. K. (2006). Motivation, governance, and the viability of hybrid forms in open source software development. Management Science, 52(7), 1000-1014.

Shao, B., Shi, L., Xu, B., \& Liu, L. (2012). Factors affecting participation of solvers in crowdsourcing: an empirical study from China. Electronic Markets, 22(2), 73-82.

Sharif, N. (2006). Emergence and development of the national innovation systems concept. Research Policy, 35(5), 745-766.

Silvertown, J. (2009). A new dawn for citizen science. Trends in ecology \& evolution, 24(9), 467-471.

Sloane, P. (2011). The brave new world of open innovation. Strategic Direction, 27(5), 3-4.

Spithoven, A., Clarysse, B., \& Knockaert, M. (2011). Building absorptive capacity to organise inbound open innovation in traditional industries. Technovation, 31(1), 1021.

Staudenmayer, N., Tripsas, M., \& Tucci, C. L. (2005). Interfirm modularity and its implications for product development. Journal of Product Innovation Management, 22(4), 303-321.

Stieger, D., Matzler, K., Chatterjee, S., \& Ladstaetter-Fussenegger, F. (2012). Democratizing strategy: How crowdsourcing can be used for strategy dialogues. California Management Review, 54(4), 44-68.

Sun, Y., Fang, Y., \& Lim, K. H. (2012). Understanding sustained participation in transactional virtual communities. Decision Support Systems, 53(1), 12-22.

Su, H. N., \& Lee, P. C. (2012). Framing the structure of global open innovation research. Journal of Informetrics, 6(2), 202-216.

Surowiecki, J. (2005). The wisdom of crowds - why the many are smarter than the few, Anchor Books Edition, New York, NY.

Teirlinck, P., Dumont, M., \& Spithoven, A. (2010). Corporate decision-making in R\&D outsourcing and the impact on internal R\&D employment intensity. Industrial and Corporate Change, 19(6), 1741-1768.

Trott, P., \& Hartmann, D. A. P. (2009). Why 'open innovation' is old wine in new bottles. International Journal of Innovation Management, 13(04), 715-736.

Trumbull, D. J., Bonney, R., Bascom, D., \& Cabral, A. (2000). Thinking scientifically during participation in a citizen-science project. Science Education, 84(2), 265-275.

Tucci, C. L., Chesbrough, H., Piller, F., \& West, J. (2016). When do firms undertake open, collaborative activities? Introduction to the special section on open innovation and open business models. Industrial and Corporate Change, 25(2), 283-288.

van de Vrande, V., De Jong, J. P., Vanhaverbeke, W., \& De Rochemont, M. (2009). Open innovation in SMEs: Trends, motives and management challenges. Technovation, 29(6), 423-437.

van Hemert, P., Nijkamp, P., \& Masurel, E. (2013). From innovation to commercialization through networks and agglomerations: analysis of sources of innovation, innovation capabilities and performance of Dutch SMEs. The Annals of Regional Science, $50(2), 425-452$. 
Vanhaverbeke, W., Van de Vrande, V., \& Chesbrough, H. (2008). Understanding the advantages of open innovation practices in corporate venturing in terms of real options. Creativity and Innovation Management, 17(4), 251-258.

von Hippel, E., \& Krogh, G. V. (2003). Open source software and the "private-collective" innovation model: Issues for organization science. Organization Science, 14(2), 209-223.

von Hippel, E. A., \& Von Krogh, G. (2006). Free revealing and the private-collective model for innovation incentives. $R \& D$ Management, 36(3), 295-306.

von Hippel, E. A. (2005). Democratizing innovation. Cambridge, MA: MIT Press

Wagner, E. B. (2011). Why prize? The surprising resurgence of prizes to stimulate innovation. Research-Technology Management, 54(6), 32-36.

West, J., \& Gallagher, S. (2006). Challenges of open innovation: the paradox of firm investment in open-source software. $R \& D$ Management, 36(3), 319-331.

West, J., \& Lakhani, K. R. (2008). Getting clear about communities in open innovation. Industry and Innovation, 15(2), 223-231.

West, J., Salter, A., Vanhaverbeke, W., \& Chesbrough, H. (2014). Open innovation: The next decade. Research Policy, 43(5), 805-811.

West, J., \& Bogers, M. (2014). Leveraging external sources of innovation: A review of research on open innovation. Journal of Product Innovation Management, 31(4), 814-831.

West, J., Salter, A., Vanhaverbeke, W., \& Chesbrough, H. (2014). Open innovation: The next decade. Research Policy, 43(5), 805-811.

West, J., Vanhaverbeke, W., Chesbrough, H. (2006). Open innovation: a research agenda. In: Chesbrough, H., Vanhaverbeke, W., West, J. (Eds.), Open Innovation: Researching a New Paradigm. Oxford University Press, Oxford, pp. 285-307.

Whitla, P. (2009). Crowdsourcing and its application in marketing activities. Contemporary Management Research, 5(1), 15-28.

Wikhamn, B. R., \& Wikhamn, W. (2013). Structuring of the open innovation field. Journal of Technology Management \& Innovation, 8(3), 173-185.

Yin, R. K. (2013). Case study research: Design and methods, Sage Publications.

Zheng, H., Li, D., \& Hou, W. (2011). Task design, motivation, and participation in crowdsourcing contests. International Journal of Electronic Commerce, 15(4), 5788. 


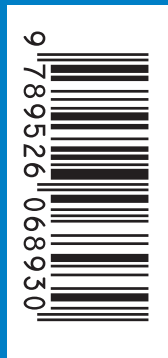

ISBN 978-952-60-6893-0 (printed)

ISBN 978-952-60-6894-7 (pdf)

ISSN-L 1799-4934

ISSN 1799-4934 (printed)

ISSN 1799-4942 (pdf)

Aalto University

Department of Industrial Engineering and Management www.aalto.fi

DESIGN +

ARCHITECTURE

SCIENCE +

TECHNOLOGY

CROSSOVER

DOCTORAL

DISSERTATIONS 